This document was prepared in conjunction with work accomplished under Contract No. DE-AC09-96SR18500 with the U. S. Department of Energy.

\title{
DISCLAIMER
}

This report was prepared as an account of work sponsored by an agency of the United States Government. Neither the United States Government nor any agency thereof, nor any of their employees, nor any of their contractors, subcontractors or their employees, makes any warranty, express or implied, or assumes any legal liability or responsibility for the accuracy, completeness, or any third party's use or the results of such use of any information, apparatus, product, or process disclosed, or represents that its use would not infringe privately owned rights. Reference herein to any specific commercial product, process, or service by trade name, trademark, manufacturer, or otherwise, does not necessarily constitute or imply its endorsement, recommendation, or favoring by the United States Government or any agency thereof or its contractors or subcontractors. The views and opinions of authors expressed herein do not necessarily state or reflect those of the United States Government or any agency thereof. 


\section{DEFINITION OF AN ACCEPTABLE GLASS COMPOSITION REGION (AGCR) VIA AN INDEX SYSTEM AND A PARTITIONING FUNCTION}

D.K. Peeler

A.S. Taylor

T.B. Edwards

June 2005

Immobilization Technology Section

Savannah River National Laboratory

Aiken, SC 29808 
WSRC-TR-2005-00239

Revision 0

\section{DISCLAIMER}

This report was prepared by Westinghouse Savannah River Company (WSRC) for the United States Department of Energy under Contract No. DE-AC09-96SR18500 and is an account of work performed under that contract. Neither the United States Department of Energy, nor WSRC, nor any of their employees makes any warranty, expressed or implied, or assumes any legal liability or responsibility for the accuracy, completeness, or usefulness, of any information, apparatus, or product or process disclosed herein or represents that its use will not infringe privately owned rights. Reference herein to any specific commercial product, process, or service by trademark, name, manufacturer or otherwise does not necessarily constitute or imply endorsement, recommendation, or favoring of same by WSRC or by the United States Government or any agency thereof. The views and opinions of the authors expressed herein do not necessarily state or reflect those of the United States Government or any agency thereof. 
Key Words: durability, DWPF

Retention: Permanent

\section{DEFINITION OF AN ACCEPTABLE GLASS COMPOSITION REGION (AGCR) VIA AN INDEX SYSTEM AND A PARTITIONING FUNCTION}

D.K. Peeler

A.S. Taylor

T.B. Edwards

June 2005

Immobilization Technology Section

Savannah River National Laboratory

Aiken, SC 29808

Prepared for the U.S. Department of Energy Under Contract Number DEAC09-96SR18500

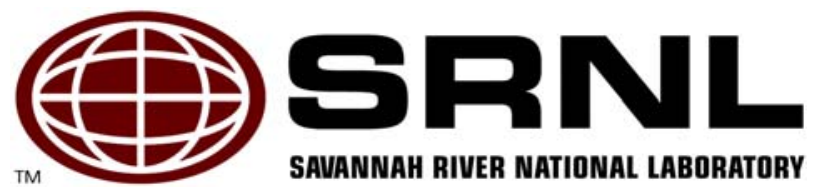




\section{REVIEWS AND APPROVALS}

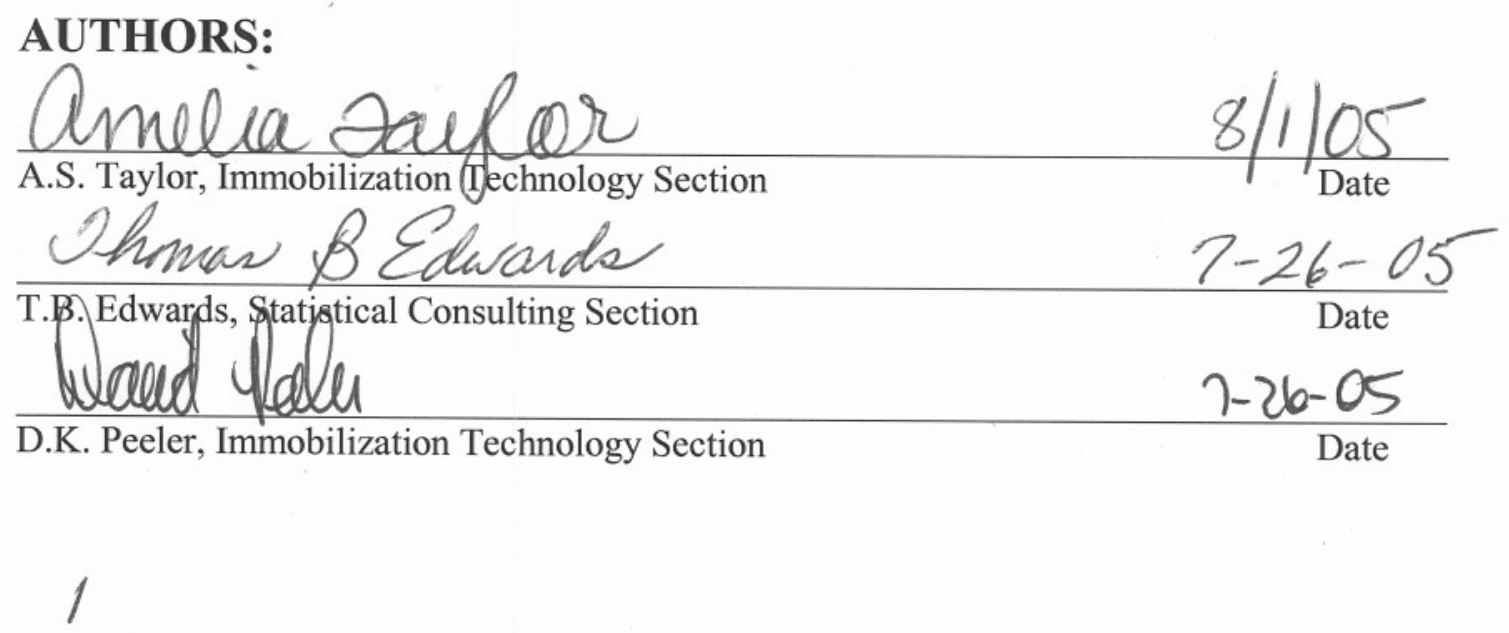

TECHNICAL REVIEWER:

Conni Alermar

C.C. Herman, Immobilization Technology Section

1.26 .05

Date

\section{APPROVERS:}

Evitretzonkte

$8 / 8101^{-}$

E.W. Holtzscheiter, Manager, Immobilization Technology Section

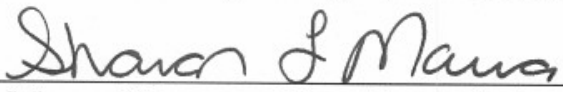

Date

S.L. Marra, Manager, Glass Formulation \& Process Development

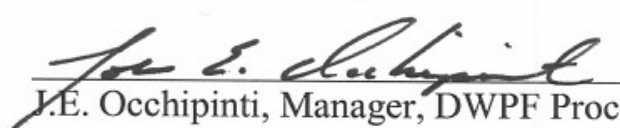

J.E. Occhipinti, Manager, DWPF Process Engineering

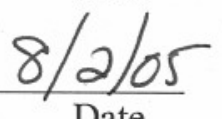

Date

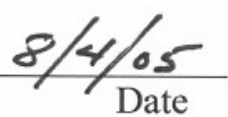




\section{EXECUTIVE SUMMARY}

The objective of this investigation was to appeal to the available ComPro ${ }^{\mathrm{TM}}$ database of glass compositions and measured PCTs that have been generated in the study of High Level Waste (HLW)/Low Activity Waste (LAW) glasses to define an Acceptable Glass Composition Region (AGCR). The term AGCR refers to a glass composition region in which the durability response (as defined by the Product Consistency Test (PCT)) is less than some pre-defined, acceptable value that satisfies the Waste Acceptance Product Specifications (WAPS) - a value of $10 \mathrm{~g} / \mathrm{L}$ was selected for this study. To assess the effectiveness of a specific classification or index system to differentiate between acceptable and unacceptable glasses, two types of errors (Type I and Type II errors) were monitored. A Type I error reflects that a glass with an acceptable durability response (i.e., a measured $\mathrm{NL}[\mathrm{B}]<10 \mathrm{~g} / \mathrm{L}$ ) is classified as unacceptable by the system of composition-based constraints. A Type II error occurs when a glass with an unacceptable durability response is classified as acceptable by the system of constraints.

Over the course of the efforts to meet this objective, two approaches were assessed. The first (referred to as the "Index System") was based on the use of an evolving system of compositional constraints which were used to explore the possibility of defining an AGCR. This approach was primarily based on "glass science" insight to establish the compositional constraints. Assessments of the Brewer and Taylor Index Systems did not result in the definition of an AGCR. Although the Taylor Index System minimized Type I errors which allowed access to composition regions of interest to improve melt rate or increase waste loadings for DWPF as compared to the current durability model, Type II errors were also committed. In the context of the application of a particular classification system in the process control system, Type II errors are much more serious than Type I errors. A Type I error only reflects that the particular constraint system being used is overly conservative (i.e., its application restricts access to glasses that have an acceptable measured durability response). A Type II error results in a more serious misclassification that could result in allowing the transfer of a Slurry Mix Evaporator (SME) batch to the melter, which is predicted to produce a durable product based on the specific system applied but in reality does not meet the defined "acceptability" criteria. More specifically, a nondurable product could be produced in DWPF. Given the presence of Type II errors, the Index System approach was deemed inadequate for further implementation consideration at the DWPF.

The second approach (the JMP partitioning process) was purely data driven and empirically derived - glass science was not a factor. In this approach, the collection of composition durability data in ComPro was sequentially partitioned or split based on the best available specific criteria and variables. More specifically, the JMP software chose the oxide $\left(\mathrm{Al}_{2} \mathrm{O}_{3}\right.$ for this dataset) that most effectively partitions the PCT responses (NL [B]'s) - perhaps not $100 \%$ effective based on a single oxide. Based on this initial split, a second request was made to split a particular set of the "Y" values (good or bad PCTs based on the $10 \mathrm{~g} / \mathrm{L}$ limit) based on the next most critical "X" variable. This "splitting" or "partitioning” process was repeated until an AGCR was defined based on the use of only 3 oxides $\left(\mathrm{Al}_{2} \mathrm{O}_{3}, \mathrm{CaO}\right.$, and $\left.\mathrm{MgO}\right)$ and critical values of $>3.75 \mathrm{wt} \% \mathrm{Al}_{2} \mathrm{O}_{3}, \geq 0.616 \mathrm{wt} \% \mathrm{CaO}$, and $<3.521 \mathrm{wt} \% \mathrm{MgO}$. Using this set of criteria, the ComPro database was partitioned in which no Type II errors were committed. The automated partitioning function screened or removed 978 of the 2406 ComPro glasses which did cause some initial concerns regarding excessive conservatism regardless of its ability to identify an AGCR. However, a preliminary review of glasses within the 1428 "acceptable" glasses defining the ACGR includes glass systems of interest to support the accelerated mission. 
With respect to implementation, having a 3-component system to classify the durability response of multi-component borosilicate glasses is conceptually "troubling”. However, one has to acknowledge its effectiveness (100\% accurate in eliminating Type II errors while not overly conservative in terms of committing Type I errors based on the historical data evaluated). In addition, a three component system to assess durability may be advantageous with respect to minimizing the number of components required for measurement to support process control. Although there are potential advantages to this approach, one also has to acknowledge the presence of potential limitations and/or implementation issues which primarily revolve around the lack of technical maturity.

Based on the results, it is recommended that further development of (or adjustments to) the Taylor Index System to define an AGCR not be considered. However, the definition of an AGCR via the JMP partitioning function does have potential advantages that should be explored. These not only include access to compositional regions of interest (beyond that defined by the current durability model using the "new" limits as proposed by Edwards et al. (2003)) but also potential advantages regarding the limited number of components needed to define the AGCR with respect to alternative process control strategies or supporting decisions regarding variability study requirements or needs. 


\section{TABLE OF CONTENTS}

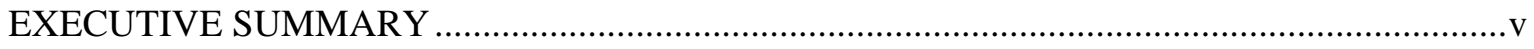

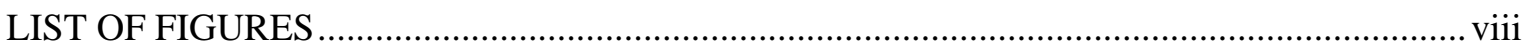

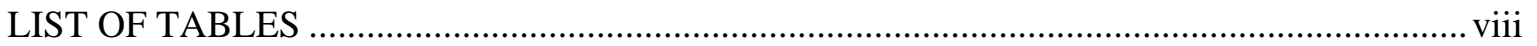

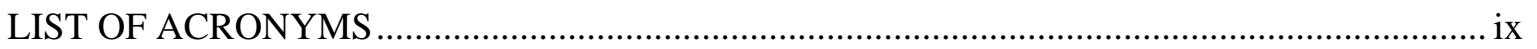

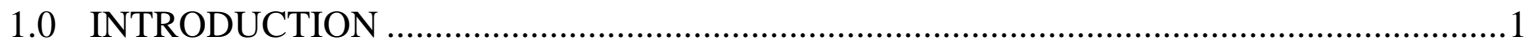

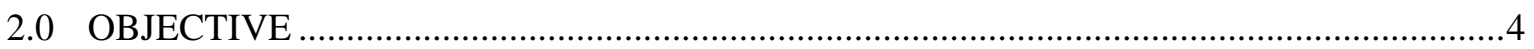

3.0 DEFINITIONS, ASSUMPTIONS, AND BASIS FOR COMPARISON ..............................6

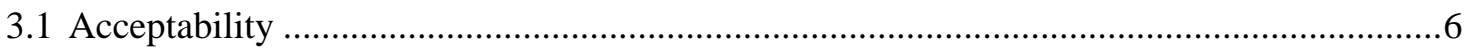

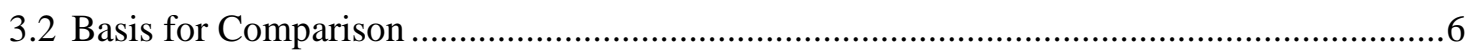

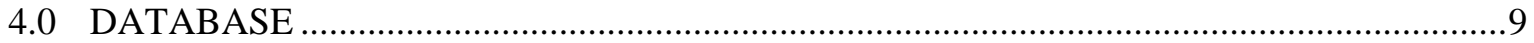

5.0 APPLICATION AND EVOLUTION OF THE INDEX SYSTEM .......................................11

5.1 Direct Application of the Brewer Index system .........................................................11

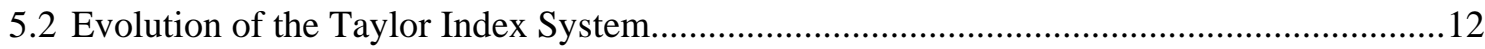

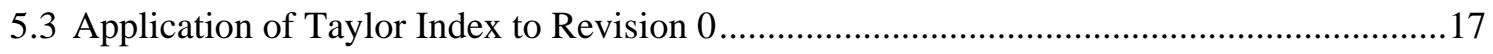

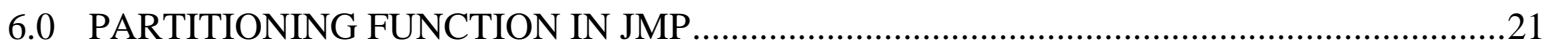

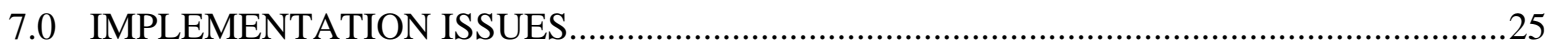

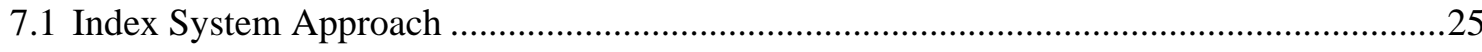

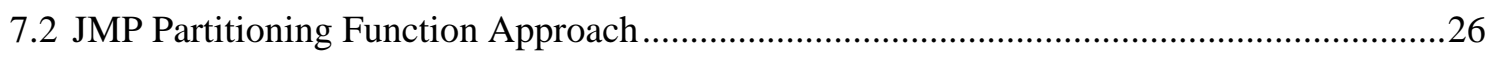

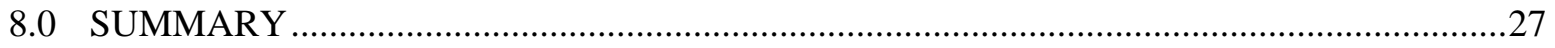

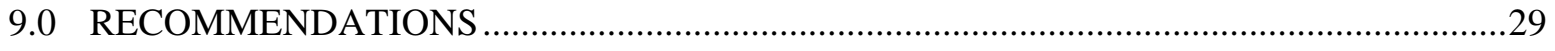

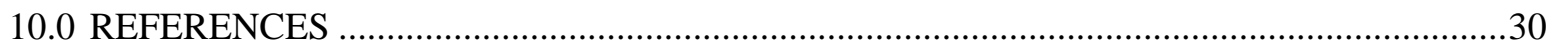

APPENDIX A. MINIMUM AND MAXIMUM VALUES DEFINING THE DURABLE AGCR

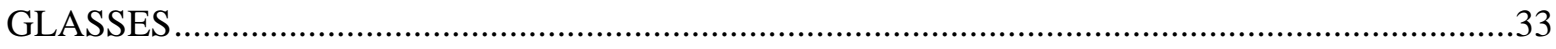




\section{LIST OF TABLES}

Table 3-1. Leachate Concentrations of the EA Glass as Reported by Jantzen et al. (1993) ....... 6

Table 3-2. Conceptual Basis for Defining Type I and Type II Errors............................................ 8

Table 5-1. Brewer Index System (from Brewer et al. 2003). ....................................................... 11

Table 5-2. Results of the Brewer Index System Applied to the Compiled Database................... 12

Table 5-3. Projected Compositional Regions for DWPF and Hanford (Wt\%). ........................... 13

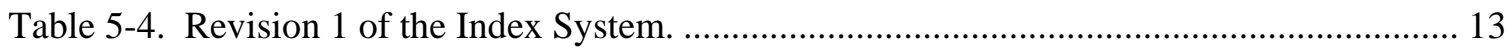

Table 5-5. Classification Summary Using Revision 1 of Brewer Index System.......................... 14

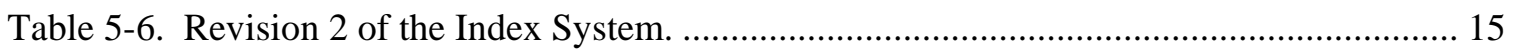

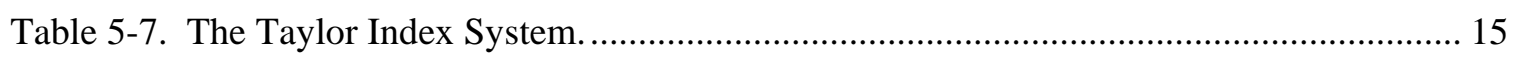

Table 5-8. Classification Summary Using the Taylor Index System...................................... 16

Table 5-9 Classification Summary Using the Taylor Index System to ComPro Revision 0 .......18

Table 5-10 Compositional Views (wt\%) of the Eight Type II Error Glasses................................18

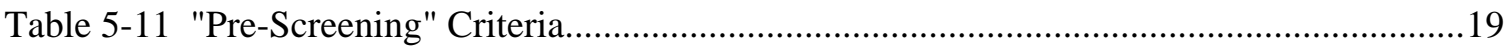

Table 5-12 Summary of Type I and Type II Errors After Applying the Taylor Index System to

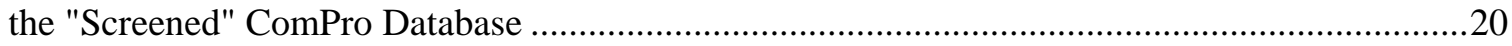

Table 6-1 Minimum and Maximum Oxide Values (Major Oxides Only) of the AGCR...............24

Table A.1 Minimum and Maximum Oxide Ranges Defining the AGCR ....................................34

\section{LIST OF FIGURES}

Figure 2-1 ..Conceptual Overview of the Index System and AGCR.......................................... 4

Figure 3-1 Conceptual Overview of the Index System and AGCR with Errors.......................... 7

Figure 5-1 Taylor Index System Versus log NL [B] Release (g/L) for Model Data .................. 17

Figure 7-1 Historical Data, the Goal for the Index System, and the Current Status...................24 


\section{LIST OF ACRONYMS}

$\begin{array}{ll}\text { AGCR } & \text { Acceptable Glass Composition Region } \\ \text { ASTM } & \text { American Society for Testing and Materials } \\ \text { cCC } & \text { centerline canister cooled } \\ \text { DOE } & \text { Department of Energy } \\ \text { DWPF } & \text { Defense Waste Processing Facility } \\ \text { EA } & \text { Environmental Assessment } \\ \text { HLW } & \text { high-level waste } \\ \text { INEEL } & \text { Idaho National Engineering and Environmental Laboratory } \\ \text { LAW } & \text { low-activity waste } \\ \text { MAR } & \text { Measurement Acceptability Region } \\ \text { NL [B] } & \text { normalized boron release (in g/L) } \\ \text { PAR } & \text { Property Acceptability Region } \\ \text { PCCS } & \text { Product Composition Control System } \\ \text { PNNL } & \text { Pacific Northwest National Laboratory } \\ \text { PCT } & \text { Product Consistency Test } \\ \text { Q } & \text { quenched } \\ \text { RC } & \text { Reduction of Constraints } \\ \text { SB } & \text { sludge batch } \\ \text { SME } & \text { Slurry Mix Evaporator } \\ \text { SRNL } & \text { Savannah River National Laboratory } \\ \text { TTR } & \text { Technical Task Request } \\ \text { WAPS } & \text { Waste Acceptance Product Specifications } \\ \text { WL } & \text { waste loading } \\ \text { WVDP } & \text { West Valley Demonstration Project } \\ & \end{array}$


WSRC-TR-2005-00239

Revision 0

\subsection{INTRODUCTION}

The Defense Waste Processing Facility's (DWPF) vitrification process is controlled using modelbased algorithms and other compositional constraints to ensure processability of the feed ("sludge-only" or "coupled" operations) through the melter as well as the durability of the final product. The DWPF process control system (namely the Product Composition Control System (PCCS)) imposes several constraints on the composition of the contents of the Slurry Mix Evaporator (SME) to define acceptability. These constraints relate process or product properties to composition via predictive models. Samples of the waste/frit blend are taken from the SME, the compositions determined, and properties are predicted from the measured compositions and are verified to a high confidence level to be within an acceptable processing window. A batch is deemed acceptable (or processable) if its composition measurements lead to acceptable property predictions after accounting for modeling, analytic, and measurement uncertainties. Brown, Postles, and Edwards (2002) provide a detailed discussion of the SME acceptability process. Once the SME product is rendered acceptable in terms of the property predictions, the feed is transferred to the melter, converted to molten glass, and poured into canisters. This feed-forward process control strategy has been very effective in terms of assuring processability and product quality.

The process control models have also played an integral role in support of the Department of Energy (DOE) accelerated mission goals. More specifically, recent glass formulation efforts have utilized the models to project operating windows (expressed in terms of waste loading (WL) intervals) for various waste - frit blends in an attempt to identify and select frits that maximize WL opportunities. In addition to WL improvements, glass formulation efforts have been focused on enhancements to melt rate which, when coupled with WL, ultimately play a major role in defining waste throughput for the DWPF.

With respect to improving melt rate, the general trend has been to enhance the total alkali concentration in the glass system by increasing the alkali concentration in the frit, utilizing (or targeting) a less washed sludge, or using a combination of the two (Lambert et al. 2001). Previous studies (Peeler and Edwards 2002; Peeler et al. 2004a) have indicated that as higher alkali glass systems are pursued, a transition can occur in which predictions of durability and/or low viscosity begin limiting upper waste loadings rather than predictions of liquidus temperature - the limiting property for current (Frit 418/Sludge Batch 3) and previous DWPF sludge batch processing. Peeler et al. (2001), Cozzi et al. (2003), and Peeler et al. (2004b) suggested that the current durability model can lead to conservative decisions during the SME acceptability process. $^{1}$ More specifically, the model (using its original limits) has restricted access to glass composition regions that could potentially enhance melt rate, WL, or waste throughput by classifying a specific glass composition as "unacceptable" whose experimentally determined durability (as defined by the Product Consistency Test (PCT) (ASTM 2002)) is "acceptable" relative to the Environmental Assessment (EA) glass (Jantzen et al. 1993). For example, Peeler et al. (2001) found that the Frit 304/Sludge Batch 2 (SB2) system was classified as unacceptable (based on model predictions of durability) but when durability was experimentally determined, the results were well below the acceptance limits (e.g., $1.07 \mathrm{~g} / \mathrm{L}$ compared to $16.695 \mathrm{~g} / \mathrm{L}$ reported for EA). Melt rate assessments indicated this frit melted 20\% faster than Frit 320 for SB2 potentially a significant opportunity missed as a result of not being able to implement this frit in

\footnotetext{
${ }^{1}$ Given the conservatism in the original $\Delta \mathrm{G}_{\mathrm{P}}$ limits, Edwards et al. (2004) provide a detailed discussion of the development of alternative (or less conservative) durability limits within the existing $\Delta \mathrm{G}_{\mathrm{P}}$ structure. These new $\Delta \mathrm{G}_{\mathrm{P}}$ limits have been proposed for implementation at DWPF but are not currently being used for the SB3 system.
} 
DWPF based on the conservatism associated with the model's prediction. More recent results (Peeler et al. 2004b) assessed the potential use of Frit 320 with SB3. As with the Frit 304 - SB2 system, the high alkali content of Frit 320 when coupled with SB3 resulted in predictions of durability restricting its potential recommendation. Experimental determination of durability for two glasses within the Frit 320 - SB3 system (at 35 and 40\% WL, ADT-5 and ADT-6, respectively) resulted in normalized boron releases (NL [B]) of $\sim 1.5 \mathrm{~g} / \mathrm{L}$ and $\sim 2.0 \mathrm{~g} / \mathrm{L}$, respectively. Subsequent assessments of melt rate by Smith et al. (2004) indicated that the melt rate for the Frit 320 - SB3 system at 35\% WL was higher than the Frit 418 - SB3 system at 35\% WL - potentially a second significant opportunity missed to increase melt rate and/or waste throughput strictly due to the conservative decisions made by the current durability model.

The incentive to access higher alkali systems to improve melt rate and/or waste loading is supported by the glass formulation efforts at Hanford for low-activity waste (LAW) (Li et al. 1995, Feng et al. 1995, Vienna et al. 2001). Certain immobilized LAW glass waste forms target a $20 \mathrm{wt} \% \mathrm{Na}_{2} \mathrm{O}$ content to meet contractual waste loading requirements (e.g., a large fraction of Hanford's LAW is high in $\mathrm{Na}_{2} \mathrm{O}$ content). Given one of the LAW glass product performance criteria is the PCT, technical inquisitiveness invokes the need to explore composition regions of interest to DWPF while extending into the high alkali regions more representative of Hanford LAW glasses. In general (and ignoring any multi-component interactions and their effects on durability), "higher" alkali glasses are expected to result in a less durable product as compared to "lower" alkali glasses. However, the line of demarcation between "low" and "high" alkali products is ill-defined, and a fundamental understanding of this distinction in classification (in terms of multi-component interactions) is needed.

In accordance with the goal of exploring higher alkali systems, DWPF issued a Technical Task Request (TTR) requesting the Savannah River National Laboratory (SRNL) to assess alternative durability options that may provide access to composition regions of interest in support of the accelerated clean-up mission (Occhipinti 2003). In response to the TTR, Peeler et al. (2003) outlined four alternatives that could potentially be developed and ultimately implemented in the DWPF process control strategy providing a technical basis for supporting the accelerated mission goals.

The four alternatives outlined were:

(1) reassessing and/or redefining the current $\Delta \mathrm{G}_{\mathrm{P}}$ limits in PCCS (model-based) ${ }^{2}$,

(2) developing a nonparametric approach (non-model based),

(3) developing an empirical model approach (model-based), and

(4) defining an Acceptable Glass Composition Region (AGCR) (non-model based).

The focus of this report is on the AGCR (alternative (4) as listed above). The term AGCR refers to a glass composition region in which the durability response (as defined by the PCT) is less than some pre-defined, acceptable value (see Section 3.2) that satisfies the Waste Acceptance Product Specifications (WAPS). The question of interest for this task is whether or not a set of rules and/or constraints could be established that uses the chemical compositions of the glasses to effectively partition PCT responses into two primary categories (acceptable and unacceptable) based on the measured durability response. More specifically, the intent of the AGCR is to define

\footnotetext{
${ }^{2}$ Edwards et al. (2004) provide a detailed discussion of the development of alternative durability limits within the existing $\Delta \mathrm{G}_{\mathrm{P}}$ structure. Peeler et al. (2004a and 2004b) provide insight into the potential incentives of implementing these proposed durability limits. These new limits are not currently implemented in PCCS but may be warranted for future sludge batches.
} 
WSRC-TR-2005-00239

Revision 0

a multi-dimensional composition region, through the use of single- or multi-component constraints imposed on the composition of HLW glasses, whose PCT responses are deemed acceptable. With respect to DWPF processing, acceptability decisions are based not only on product performance (durability) predictions but processing (i.e., viscosity and liquidus temperature) considerations as well. The assessments performed in this report are based solely on defining a glass composition region in which the PCT response meets the pre-defined criterion. This approach, if successful, does not compromise the integrity of the integrated systems approach as established in PCCS as ultimately the AGCR could replace predictions of durability (if proven effective), but models for processing consideration would still be used for SME acceptability decisions.

This report provides a summary of the efforts associated with developing the AGCR option as a potential alternative durability approach for DWPF. The objectives of this task as well as a conceptual overview of an ideal AGCR are defined in Section 2.0. General definitions and the basis for comparing the effectiveness of various forms of the index system are given in Section 3.0. A general description of the ComPro ${ }^{\mathrm{TM}}$ database is provided in Section 4.0. Application of the Brewer index system and the evolution of the Taylor Index System are documented in Section 5.0 in terms of the changes made and the efficiency of the revised index system to partition the ComPro data according to a predefined durability threshold value. In Section 6.0, application of an automated "partitioning" function of the JMP software is used to evaluate its ability to effectively partition the ComPro glasses. Insight into potential implementation issues is discussed in Section 7.0. Sections 8.0 and 9.0 provide a summary of the current work and recommendations, respectively. 


\subsection{OBJECTIVE}

The objective of this investigation was to appeal to the available ComPro database of glass compositions and measured PCTs that have been generated in the study of HLW/LAW glasses to define an AGCR. The term AGCR refers to a glass composition region in which the durability response (as defined by the PCT) is less than some pre-defined, acceptable value that satisfies the WAPS. The glasses in the ComPro database can be grouped by their measured PCT response into two sets: those glasses with PCTs below this acceptable value (i.e., durable glasses) and those glasses with PCTs above that value (i.e., non-durable glasses). The "acceptance" criterion or value is discussed and defined in Section 3.0. The question of interest for this task is whether or not a set of rules and constraints can be established that uses the chemical compositions of the glasses to effectively generate an effective partitioning of the PCTs. The index system described by Brewer et al. (2003) was a preliminary (scoping) attempt at such a set of rules using the Pacific Northwest National Laboratory (PNNL) database. The objective of this report is to explore the ability of this index system (or modifications to it) to partition the glasses in ComPro by durability to define an AGCR without overly restricting the compositional region. Figure 2-1 provides a conceptual overview of the index system and the AGCR.

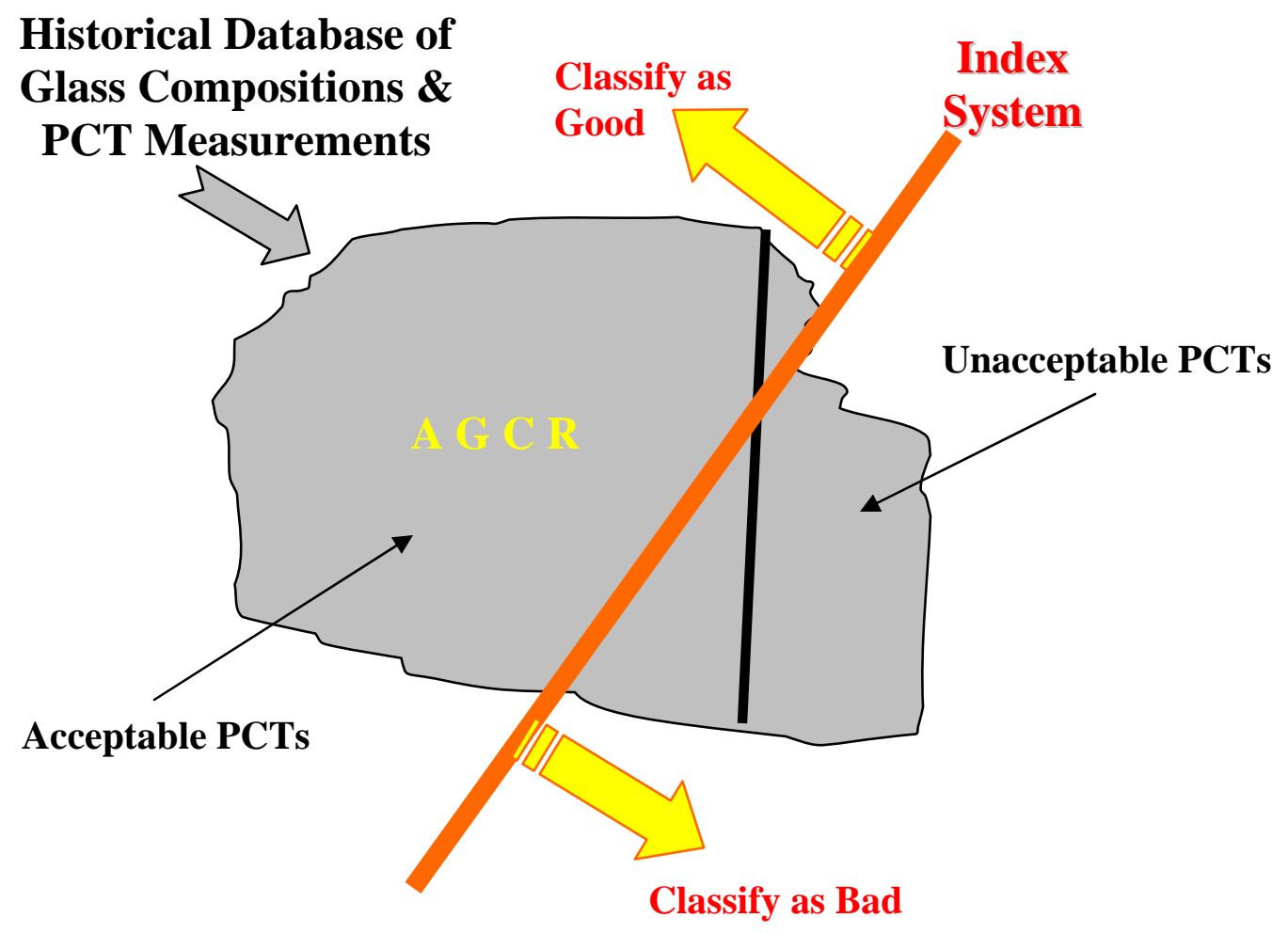

Figure 2-1. Conceptual Overview of the Index System and AGCR

In this figure, the shaded region represents the historically available data of glass compositions and measured PCTs. The bold (nearly vertical) black line separates these glasses in PCT-space into two groups (as labeled in the figure): those glasses whose measured PCTs were below the acceptable value (these "acceptable" glasses are to the left of the bold line) and those glasses 
whose measured PCTs exceeded the acceptable value (these glasses have unacceptable PCTs and are to the right of the bold line). The index system (a set of rules and/or constraints imposed on the glass compositions) is also represented in the figure. It is shown as a bold red line (nearly at a $45^{\circ}$ angle), and it is used to classify glasses as "good" or "bad" relative to their anticipated PCT responses based solely on their chemical compositions. An AGCR would be realized by an ideal index system if the bold red line overlaid the bold black line. Under these conditions, the index system would perfectly partition the glasses into the two sets of PCTs using only the chemical compositions of the glasses and would define an AGCR, the glass composition region that could be targeted for DWPF operation since the region consists of only glasses that yield acceptable PCTs based on a predefined criterion meeting the WAPS. In addition to effectively partitioning the glasses in terms of their durability response, another critical factor to consider is the ability of the Index System to provide access to compositional regions of interest to support the accelerated mission goals. More specifically, developing a Index System that defines an AGCR but restricts assess to higher alkali regions which have been shown to improve melt rate and/or waste loading does not improve upon the use of the current durability model. The new "model” must not only reduce conservatism but also provide a sound technical basis from which acceptability decisions can be made. 
WSRC-TR-2005-00239

Revision 0

\subsection{DEFINITIONS, ASSUMPTIONS, AND BASIS FOR COMPARISON}

\subsection{Acceptability}

Although durability is a function of the overall glass composition, the limits for an "acceptable" glass product are defined by the WAPS. The WAPS states (WAPS 1996): "For acceptance, the mean concentrations of lithium, sodium, and boron in the leachate, after normalizing for the concentrations in the glass, shall each be less than those of the benchmark glass described in the Environmental Assessment for selection of the DWPF waste form. One acceptable method of demonstrating that the acceptance criteria are met would be to assure that the mean PCT results for each waste type are at least two standard deviations below the mean results of the Environmental Assessment (EA) glass.” Table 3-1 shows the normalized releases for boron, lithium, and sodium for the EA glass as reported by Jantzen et al. (1993).

Table 3-1. Leachate Concentrations of the EA Glass as Reported by Jantzen et al. (1993)

\begin{tabular}{|l|c|c|c||}
\cline { 2 - 4 } \multicolumn{1}{c|}{} & \multicolumn{3}{c||}{ Leachate Concentrations } \\
\cline { 2 - 4 } \multicolumn{1}{c|}{} & $\mathbf{B}(\mathbf{g} / \mathbf{L})$ & $\mathbf{L i}(\mathbf{g} / \mathbf{L})$ & $\mathbf{N a}(\mathbf{g} / \mathbf{L})$ \\
\hline Mean & 16.695 & 9.565 & 13.346 \\
\hline Standard Deviation & 1.222 & 0.735 & 0.902 \\
\hline
\end{tabular}

In this report, the term "acceptable" (in reference to a PCT response) is defined as a glass whose $\log \mathrm{NL}[\mathrm{B}]$ is less than $1.0 \mathrm{~g} / \mathrm{L}$ (or NL $[\mathrm{B}]<10 \mathrm{~g} / \mathrm{L}$ ). This is consistent with the limit used by Edwards and Brown (1998) to set the $\Sigma$ alkali and $\mathrm{Al}_{2} \mathrm{O}_{3}$ criteria for relaxing the homogeneity constraint from the Measurement Acceptability Region (MAR) to the Property Acceptability Region (PAR). This definition is also considered to be conservative relative to the EA glass as reported by Jantzen et al. (1993) with uncertainties considered as well as conservative relative to the requirements as specified in the WAPS.

\subsection{Basis for Comparison}

During the development of the initial index system, Brewer et al. (2003) provided guidance on how to assess the effectiveness of a specific classification or index system to differentiate between acceptable and unacceptable glasses. They noted that two types of errors could be observed: Type I and Type II errors. A Type I error occurs when a glass with an acceptable durability response (i.e., a measured $\mathrm{NL}[\mathrm{B}]<10 \mathrm{~g} / \mathrm{L}$ ) is classified as unacceptable by the system of composition-based constraints. A Type II error occurs when a glass with an unacceptable durability response is classified as acceptable by the system of constraints. Figure 3-1 shows a modification of Figure 2-1 to reveal occurrences of these two types of errors: 


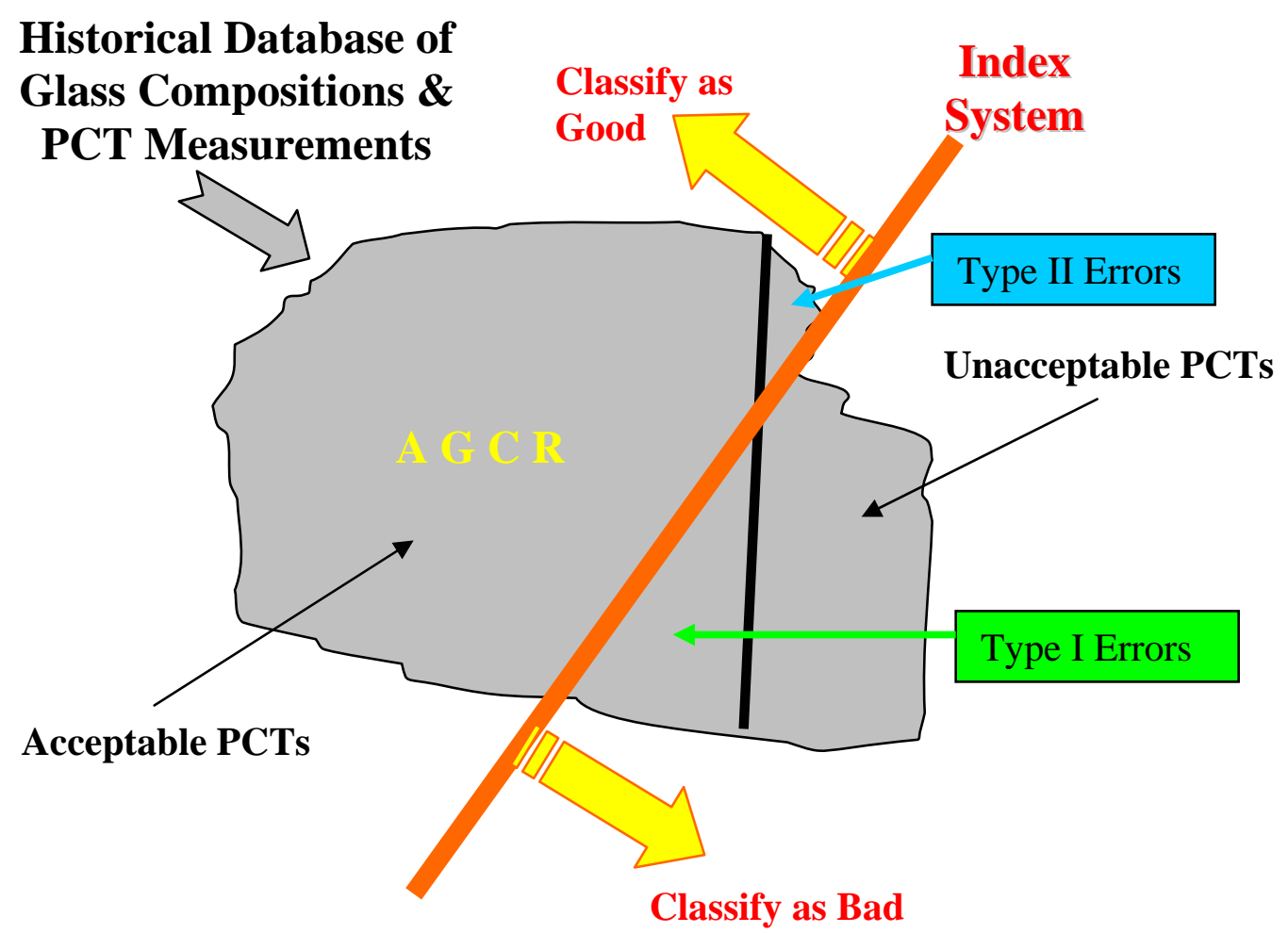

Figure 3-1. Conceptual Overview of the Index System and AGCR with Errors

A general situation is shown in Table 3-2. Consider that there are a total of $\mathrm{M}$ glasses with acceptable durabilities (NL [B] $<10 \mathrm{~g} / \mathrm{L}$ ) and a total of $\mathrm{N}$ glasses with unacceptable durability (NL $[B] \geq 10 \mathrm{~g} / \mathrm{L}$ ). The number of Type I errors is designated by " $\mathrm{m}$ ", while the number of Type II errors is designated by " $n$ ”. 
WSRC-TR-2005-00239

Revision 0

Table 3-2. Conceptual Basis for Defining Type I and Type II Errors.

\begin{tabular}{|c|c|c|c|}
\hline & & Glass Classific & n by Constraints \\
\hline & & Acceptable & Unacceptable \\
\hline Total = M glasses & $\frac{0}{\frac{0}{\sigma}}$ & $\begin{array}{l}\text { Correct } \\
M-m\end{array}$ & $\begin{array}{c}\text { Type I Error } \\
\text { m }\end{array}$ \\
\hline & ลั & $\mathbf{M}$ & $\mathbf{M}$ \\
\hline$\frac{\pi}{2}$ & U్ర & $\begin{array}{l}\text { Acceptable Glasses Classified } \\
\text { Correctly by Constraints }\end{array}$ & $\begin{array}{l}\text { Acceptable Glasses Classified } \\
\text { Incorrectly by Constraints }\end{array}$ \\
\hline U্র & $\frac{0}{\frac{0}{0}}$ & $\begin{array}{c}\text { Type II Error } \\
\mathbf{n} \\
\end{array}$ & $\begin{array}{c}\text { Correct } \\
N-n\end{array}$ \\
\hline Total = N glasses & d & $\mathbf{N}$ & $\mathbf{N}$ \\
\hline & 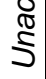 & $\begin{array}{c}\text { Unacceptable Glasses Classified } \\
\text { Incorrectly by Constraints }\end{array}$ & $\begin{array}{c}\text { Unacceptable Glasses Classified } \\
\text { Correctly by Constraints }\end{array}$ \\
\hline
\end{tabular}

In the context of the application of a particular classification system in the process control system, Type II errors are much more serious than Type I errors. A Type I error only reflects that the particular constraint system being used is overly conservative (i.e., its application restricts access to glasses that have an acceptable measured durability response). A Type II error results in a more serious misclassification that could result in allowing the transfer of a SME batch to the melter, which is predicted to produce a durable product based on the specific system applied but in reality does not meet the defined "acceptability" criteria. More specifically, a non-durable product could be produced in DWPF.

An AGCR would be realized by an ideal index system that once applied contained no Type I or Type II errors (i.e., the bold red line overlaid the bold black line in Figure 2-1 or Figure 3-1). That is, the index system would perfectly partition the glasses into the two sets of PCTs using only the chemical compositions of the glasses and would define an AGCR.

As demonstrated by Brewer et al. (2003), the Type I and Type II metrics can be used to assess whether the addition (or deletion) of a specific composition constraint or a change in magnitude had a positive or negative impact on the ability of the system to effectively partition the database with respect to durability. These metrics provided "instant feedback" to proposed constraint changes and, therefore, will be used to assess the application of the Brewer Index system to the compiled ComPro database or to guide subsequent revisions.

In this study, the following "up front” assumptions were made. The Type I and Type II metrics would be used as a guide to assess the Brewer index system (or revision) in terms of effectively developing an AGCR. The ultimate goal was to develop an "ideal" system which partitioned the measured durability responses based on composition without committing any Type II errors while allowing access to composition regions of interest. Again, developing an AGCR that eliminates Type II errors but does not provide access to compositional regions of interest does not warrant further consideration for implementation. 
WSRC-TR-2005-00239

Revision 0

\subsection{DATABASE}

The approach being assessed requires an extensive database of composition - durability information given the partitioning will be data driven. Over the past 20 years, numerous studies have been focused on the effects of glass composition on durability (as defined by the PCT) for nuclear waste glasses - both high level waste (HLW) and LAW glasses. The results of the majority of these studies are reported in the literature and publicly available. In addition, SRNL developed a database (THERMO ${ }^{\mathrm{TM}}$ ) from which the current DWPF process control models were developed (Jantzen et al. 1995). Several other studies have been completed within SRNL since the development of THERMO ${ }^{\mathrm{TM}}$ that are not associated with the database (e.g., the Reduction of Constraint (RC) studies, Frit 320 development activities, recent variability studies, etc). These studies could provide valuable insight into the effects of composition on the durability of the product as defined by the PCT.

In September 2002, PNNL issued a report in which they compiled compositional - property data (Vienna et al. 2002). The PNNL database contains some DWPF compositional data but was primarily based on the research performed at PNNL, Idaho National Engineering and Environmental Laboratory (INEEL), and the West Valley Demonstration Project (WVDP). Brewer et al. (2003) utilized the PNNL database to support the initial development and evaluation of the AGCR concept and application potential for HLW glasses.

An effort has recently been completed at SRNL to compile all relevant glass data into a single database, referred to as ComPro ${ }^{\mathrm{TM}}$ (Taylor et al. 2004). ${ }^{3}$ The ComPro database (Revision 0) contains over 73 columns of composition and PCT information for each glass (or database row) and 8501 total rows (or specific glasses). Of the 8501 total rows, 3661 rows have been classified as "Model" data and 4840 rows have been classified as "Non-Model" data based on a 2-phased assessment (both quality assurance (QA) and technical). With over 73 columns of potential composition and PCT information for each glass (or database row), and 8501 total rows of "Model” (specifically 3661 rows) and "Non-Model” (specifically 4840 rows) data, the number of possible cells entries within the ComPro database exceeds 630,000 (ignoring the data columns not associated with composition or durability). The verification and validation process indicated that the values in at least $98 \%$ of the "Model" data rows correspond accurately to the original source documents with $95 \%$ confidence. In other words, there is no more than a $2 \%$ error rate for the "Model" data rows in the database as compared to the original source documents using a predefined set of "acceptance" criteria. This effort led to the inclusion of compositions that are more representative of the glasses that have been (or could be) vitrified at DWPF. As a result, the ComPro database should provide a more relevant comparison to the application of an Index system to define an AGCR for DWPF as compared to the initial assessments performed by Brewer et al. (2003) given the use of primarily Hanford-based waste glasses.

The composition information (provided as a wt\% oxide) for a glass could include up to three compositional views: target, measured, and measured bias-corrected. PCT information (provided in $\mathrm{g} / \mathrm{L}$ for normalized $\mathrm{B}, \mathrm{Li}, \mathrm{Na}$, and/or Si releases) could be available for both quenched (Q) or

\footnotetext{
${ }^{3}$ As discussed in this report, the development of the Taylor Index System (a revision to the Brewer Index System) was performed in parallel with the compilation of the ComPro database. As a result of these parallel activities, the development or evolution of the Taylor Index System was based on a "draft" version of the ComPro database (Draft F, dated 7/19/04). This report not only discusses the evolution of the Taylor Index System using Draft F but also summarizes its application to ComPro Revision 0. It should be noted that the primary difference between Draft $\mathrm{F}$ and Revision 0 is the number of glasses that were classified as quenched, Model Data (a difference of 8 glasses).
} 
centerline canister cooled (сcc) versions of a glass for any of the composition views. For this study, only the data of ComPro classified as "Model Data" will be used. Approximately 3500 rows are classified as "Model Data" with the remaining rows being classified as "Non-Model Data". ${ }^{4}$ Further, only quenched, heat-treated glasses were used in the assessment (and refinement) of the Brewer system. The screening of the ComPro database (Draft F) described above ("Model Data" and quenched heat treatments) resulted in 2414 rows of data. Of these 2414 glasses, 161 have NL [B] $\geq 10$ g/L (non-durable), and 2253 glasses have NL [B] < 10 g/L (durable). ${ }^{5}$

As outlined by Brewer et al. (2003), a reasonable question to ask is: "Given all the data developed to evaluate compositional effects on PCT response, can the existing data be used to identify a compositional region in which acceptable glasses reside?” With the ComPro database in hand, the fundamental question driving this task is: "Can the database be used to identify a composition region in which only glasses with acceptable durability reside?” Such a region would be an AGCR to be targeted for DWPF operation in regards to the quality of the DWPF waste product.

As this durability alternative was conceived and pursued, the technical basis for defining an AGCR using the information in ComPro was questioned. The initial answer was "glass science." That is, a great deal has been learned over the course of the studies that led to the data compiled in the ComPro database, and it was hoped that this knowledge could help direct the form of the constraints on glass composition that would define an AGCR. It was anticipated that the limits of the constraints would be empirically determined using the database to restrict the composition region to successfully define an AGCR for DWPF operation. For this durability alternative to be successful, the AGCR would have to be a composition region in which only glasses with acceptable durability reside (no Type II errors). In addition, it would also have to be true that glass systems (frit/sludge batch combinations) within the AGCR could be targeted that would support the accelerated clean-up goals for DWPF operations.

\footnotetext{
${ }^{4}$ The Model Data have been screened via SRNL QA personnel to ensure that the quality of the data is either RW0333P Compliant or Equivalent. In addition, the "Model Data" were screened via a verification and validation process to compare the electronic database entries with the values as reported by the original data source (see Snyder et al. (2004)).

${ }^{5}$ It should be noted that 2406 glasses were classified as quenched, "Model Data” in ComPro Revision 0 as a result of the verification and validation process. Of these 2406 glasses, 161 have NL [B] $\geq 10 \mathrm{~g} / \mathrm{L}$, and 2245 glasses have NL [B] $<10 \mathrm{~g} / \mathrm{L}$. As a comparison, the PNNL dataset used by Brewer et al. (2003) contained 1031 entries. Of these, 96 glasses had NL $[\mathrm{B}] \geq 10 \mathrm{~g} / \mathrm{L}$, and 935 glasses had NL $[\mathrm{B}]<10 \mathrm{~g} / \mathrm{L}$.
} 


\subsection{APPLICATION AND EVOLUTION OF THE INDEX SYSTEM}

\subsection{Direct Application of the Brewer Index system}

Previous efforts by Brewer et al. (2003) showed that a scoring system based on compositional data could begin the effective (i.e., with less than $6 \%$ non-durable glasses being classified as durable - a Type II error) partitioning of the ComPro database according to durability. The Brewer index system is a 10 component scoring system that consists of a series of "If/Then" statements that result in "Good" and "Bad" indices (see Table 5-1). The "Good" index minus the "Bad" index provides a "score" that if greater than -0.24 the glass is classified as acceptable, and if less than the -0.24 value the glass is classified as unacceptable (based on the $10 \mathrm{~g} / \mathrm{L}$ limit). The components of the "Good" index are $\mathrm{Al}_{2} \mathrm{O}_{3}, \mathrm{ZrO}_{2}$, and $\mathrm{Fe}_{2} \mathrm{O}_{3}$ (which in general agree with glass science theory that these components should "improve" durability). The $\mathrm{Al}_{2} \mathrm{O}_{3}$ and $\mathrm{ZrO}_{2}$ components have upper bounding coefficients to limit the contribution of the components at higher concentrations. The "Bad" index is composed of $\mathrm{Na}_{2} \mathrm{O}, \mathrm{Li}_{2} \mathrm{O}, \mathrm{SiO}_{2}, \mathrm{~B}_{2} \mathrm{O}_{3}, \mathrm{MgO}$, and sum of alkali $\left(\mathrm{Cs}_{2} \mathrm{O}, \mathrm{K}_{2} \mathrm{O}, \mathrm{Li}_{2} \mathrm{O}\right.$, and $\left.\mathrm{Na}_{2} \mathrm{O}\right)$ with each having an upper limiting coefficient except the sum of alkali term. Again, in general, the components listed in the "Bad" index (exception being $\mathrm{SiO}_{2}$ ) are typically those that have a negative impact on durability from a glass science perspective. The use of $\mathrm{SiO}_{2}$ in the "Bad" index is explained by Brewer et al. (2003).

Table 5-1. Brewer Index System (from Brewer et al. 2003).

\begin{tabular}{||c|c|c||}
\hline \hline \multicolumn{3}{|c||}{ Good Index } \\
\hline $\mathbf{A l}_{2} \mathbf{O}_{3}$ & $\mathrm{ZrO}_{2}$ & $\mathbf{F e}_{2} \mathbf{O}_{3}$ \\
\hline If $\mathrm{Al}_{2} \mathrm{O}_{3}<8$, then & If $\mathrm{ZrO}_{2}<12$, then & $\mathrm{Fe}_{2} \mathrm{O}_{3} / 13.5$ \\
$\mathrm{Al}_{2} \mathrm{O}_{3} / 3$ & $\mathrm{ZrO}_{2} / 9$ & \\
\hline If $\mathrm{Al}_{2} \mathrm{O}_{3} \geq 8$, then $8 / 3$ & If $\mathrm{ZrO}_{2} \geq 12$, then $12 / 9$ & \\
\hline
\end{tabular}

\begin{tabular}{||c|c|c||}
\hline \multicolumn{3}{|c|}{ Bad Index } \\
\hline $\mathbf{N a}_{\mathbf{2}} \mathbf{O}$ & $\mathbf{L i}_{\mathbf{2}} \mathbf{O}$ & $\mathbf{S i O}_{\mathbf{2}}$ \\
\hline If $\mathrm{Na}_{2} \mathrm{O}>8$, then $\mathrm{Na}_{2} \mathrm{O} / 23$ & If $\mathrm{Li}_{2} \mathrm{O}>6$, then $\mathrm{Li}_{2} \mathrm{O} / 25$ & If $\mathrm{SiO}_{2}<30$, then $\left(30-\mathrm{SiO}_{2}\right) / 10$ \\
\hline $\mathbf{B}_{2} \mathbf{O}_{3}$ & $\mathbf{M g O}$ & Sum of Alkali \\
\hline If $\mathrm{B}_{2} \mathrm{O}_{3}<16$, then $\mathrm{B}_{2} \mathrm{O}_{3} / 13$ & If $3<\mathrm{MgO}<10$, then $\mathrm{MgO} / 15$ & Sum of Alkali/20 \\
\hline If $\mathrm{B}_{2} \mathrm{O}_{3} \geq 16$, then $16 / 13$ & If $\mathrm{MgO} \geq 10$, then $2 / 3$ & \\
\hline
\end{tabular}

The Brewer index system was applied to the 2414 rows of Model Data in the ComPro (Draft F) database. The results indicated both Type I and Type II errors were committed - see Table 5-2 for a summary. The Type I error rate of $43.6 \%$ which indicates excessive conservatism in the system as there are a high number of experimentally determined durable glasses that could not be processed under this system. Although the Type II error rate was only $2.48 \%$ (misclassifying only 4 of the 161 non-durable glasses), the excessive Type I error rate unnecessarily restricts access to composition regions of interest to improve melt rate and/or waste throughput. In fact, this Index System is probably more conservative than the current durability approach - a direction to be avoided. In addition, although the Type II error rate is relatively low, an AGCR was not defined. 
Since the Brewer index system was developed from primarily Hanford glasses, the direct application of the index system (without adjustments or modifications) resulting in an "ideal" AGCR for DWPF would be unlikely. More specifically, the compositional differences between the Hanford and DWPF glasses contribute to the ineffective application of the Brewer system for DWPF. Given the high \% of Type I errors and the lack of defining an AGCR, modifications to the Brewer Index System are required in order to meet programmatic objectives.

Table 5-2. Results of the Brewer Index System Applied to the Compiled Database.

\begin{tabular}{|c|c|c|c|}
\hline & \multicolumn{2}{|c|}{ Classification by Index System } \\
\hline & & Durable & Non-Durable \\
\hline \multirow{6}{*}{ 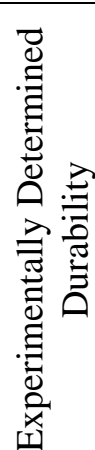 } & & $\underline{1271}$ & $\underline{982}$ \\
\hline & $\frac{0}{2}$ & $\overline{2253}$ & 2253 \\
\hline & $\bar{\emptyset}$ & Correct & $\begin{array}{c}\text { Type I Error } \\
43.6 \%\end{array}$ \\
\hline & & 4 & 157 \\
\hline & $\frac{\pi}{0}$ & $\overline{161}$ & $\overline{161}$ \\
\hline & $\begin{array}{l}0 \\
\dot{1} \\
z \\
z\end{array}$ & $\begin{array}{c}\text { Type II Error } \\
2.48 \%\end{array}$ & Correct \\
\hline \multicolumn{4}{|c|}{ Correctly Classifies EA ${ }^{6}$} \\
\hline
\end{tabular}

\subsection{Evolution of the Taylor Index System}

In this section, the chronological adjustments made to the Brewer index system to improve the classification percentage are described. ${ }^{7}$ The initial step was to ask the question: "For those glasses in which the Brewer system did not classify correctly, are there compositional similarities that can be observed and accounted for in a revised index system?”. As mentioned in Brewer et al. (2003), the upper and lower bounds of the DWPF and PNNL glasses differ to varying extents, and certain terms may need to be added, deleted, or revised to incorporate the DWPF glasses into the correct classifications. Table 5-3 shows a comparison of DWPF and Hanford composition envelopes of interest.

Using the upper and lower bounds for each oxide as a guide, the DWPF composition region can essentially be viewed as a subset of the Hanford composition region. That is, the upper and lower bounds for the DWPF region are contained within the upper and lower bounds for Hanford - with one exception: $\mathrm{U}_{3} \mathrm{O}_{8}$. The range of $\mathrm{U}_{3} \mathrm{O}_{8}$ values for DWPF encompasses those of interest to Hanford. Of additional interest is the marked difference in $\mathrm{ZrO}_{2}$ concentrations. For Hanford glasses, $\mathrm{ZrO}_{2}$ can potentially be a major component of the glass product; whereas in the DWPF composition region, $\mathrm{ZrO}_{2}$ is considered a minor component $(<0.5 \mathrm{wt} \%$ in glass as denoted by a “_“ in Table 5-3). This difference may impact the ability of the Brewer index system to

\footnotetext{
${ }^{6}$ For an index system to meet the intent of the WAPS, it must classify the EA glass as "unacceptable” based on its reference composition since it is the "benchmark" in terms of durability acceptance.

${ }^{7}$ As previously mentioned, the evolution of the Taylor Index System was based on Draft F of ComPro (2414 glasses classified as Model and Quenched). Application of the Taylor Index System to ComPro Revision 0 is discussed in Section 5.3.
} 
WSRC-TR-2005-00239

Revision 0

effectively partition the compiled database given the presence of $\mathrm{ZrO}_{2}$ can have a significant impact on the durability response.

Table 5-3. Projected Compositional Regions for DWPF and Hanford (Wt\%).

\begin{tabular}{||c|c|c|c|c||}
\hline \hline Oxide & \multicolumn{2}{|c|}{ DWPF } & \multicolumn{2}{c||}{ Hanford } \\
\hline $\mathrm{Al}_{2} \mathrm{O}_{3}$ & 3 & 15 & 0 & 25 \\
\hline $\mathrm{B}_{2} \mathrm{O}_{3}$ & 4.5 & 12 & 0.04 & 20.01 \\
\hline $\mathrm{CaO}$ & 0 & 4 & 0 & 15 \\
\hline $\mathrm{Fe}_{2} \mathrm{O}_{3}$ & 5 & 18 & 0 & 26.26 \\
\hline $\mathrm{Li}_{2} \mathrm{O}$ & 3 & 7 & 0 & 9 \\
\hline $\mathrm{MgO}$ & 0 & 4 & 0 & 8 \\
\hline $\mathrm{MnO}$ & 0 & 8 & 0 & 13.6 \\
\hline $\mathrm{Na}_{2} \mathrm{O}$ & 7.5 & 25 & 0.81 & 35 \\
\hline $\mathrm{NiO}$ & 0 & 5 & 0 & 6.3 \\
\hline $\mathrm{SiO}_{2}$ & 40 & 65 & 23.59 & 76.54 \\
\hline $\mathrm{TiO}_{2}$ & 0 & 1.75 & 0 & 8.59 \\
\hline $\mathrm{U}_{3} \mathrm{O}_{8}$ & 0 & 8 & 0 & 4.531 \\
\hline $\mathrm{ZrO}_{2}$ & - & - & 0 & 16.5 \\
\hline
\end{tabular}

Initial modifications focused solely on revising the existing "coefficients" of the Brewer index system. This effort led to the observation that the $\mathrm{SiO}_{2}$ term did not impact the dataset used for this task (no glasses contained $<30 \mathrm{wt} \% \mathrm{SiO}_{2}$ ). The $\mathrm{SiO}_{2}$ term was removed from the index system.

An additional observation was noted as the coefficients were being adjusted. This observation was that 308 of the 982 Type I error glasses contained greater than $8 \mathrm{wt} \% \mathrm{Al}_{2} \mathrm{O}_{3}$. Due to the upper limiting coefficient for glasses with greater than $8 \mathrm{wt} \% \mathrm{Al}_{2} \mathrm{O}_{3}$, a potential limiting factor in the classification of $1 / 3$ of the Type I error glasses was realized. This observation leads one to reconsider the notion that there could be an upper limit to an oxide's effect on durability. In challenging this concept, the upper limiting coefficients were removed from the index system developed by Brewer. This removed the "If/Then" statements from the scoring system resulting in the index system (referred to as Revision 1) displayed in Table 5-4.

Table 5-4. Revision 1 of the Index System.

\begin{tabular}{||c|c|c||}
\hline \multicolumn{3}{|c|}{ Good Index } \\
\hline $\mathrm{Al}_{2} \mathbf{O}_{3}$ & $\mathrm{ZrO}_{2}$ & $\mathbf{F e}_{2} \mathbf{O}_{3}$ \\
\hline $\mathrm{Al}_{2} \mathrm{O}_{3} / 3$ & $\mathrm{ZrO}_{2} / 9$ & $\mathrm{Fe}_{2} \mathrm{O}_{3} / 13.5$ \\
\hline
\end{tabular}

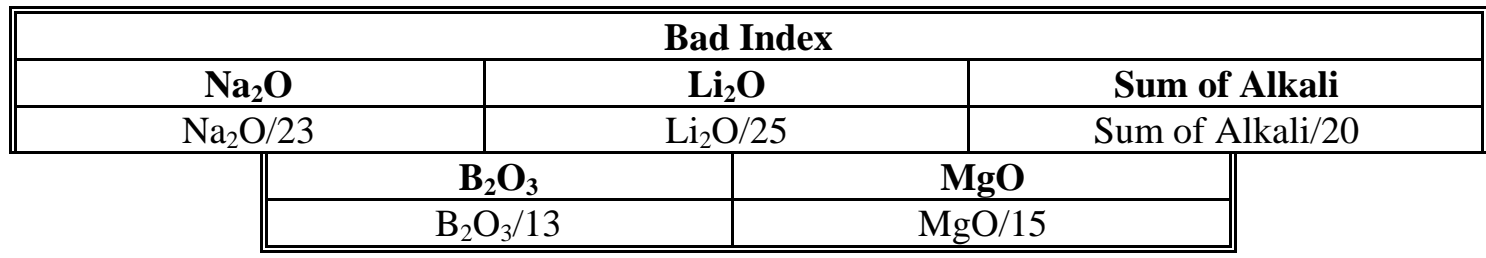


WSRC-TR-2005-00239

Revision 0

This revised index system was reapplied to the ComPro dataset (i.e., the 2414 rows of data in Draft F). A summary of the results is shown in Table 5-5. The total errors decreased from 986 (with the original Brewer index system - see Table 5-2) to 342. This revised system effectively decreased the Type I error percentage rate (a reduction from $43.6 \%$ with the original Brewer system to 14.8\%). The potential advantage of this system is that it appears to be less conservative and could potentially allow access to composition regions of interest to improve melt rate or increase waste loading. However, definition of an AGCR was not achieved; in fact, there was an increase in the number of Type II errors. Comparing the results of the Brewer Index system (applied directly to the ComPro database) with those of applying Revision 1, the challenge of developing compositional constraints to define an effective (and implementable AGCR) will be to balance the requirement for eliminating Type II errors while retaining access into compositional regions of interest (removing conservatism).

Table 5-5. Classification Summary Using Revision 1 of Brewer Index System.

\begin{tabular}{|c|c|c|c|}
\hline & \multicolumn{2}{|c|}{ Classification by Index System } \\
\hline & & Durable & Non-Durable \\
\hline \multirow{6}{*}{ 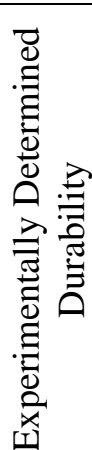 } & & $\underline{1920}$ & $\underline{333}$ \\
\hline & $\frac{\pi}{20}$ & 2253 & 2253 \\
\hline & $\overline{\mathrm{D}}$ & Correct & $\begin{array}{c}\text { Type I Error } \\
14.8 \%\end{array}$ \\
\hline & & $\underline{9}$ & 152 \\
\hline & हृ & 161 & 161 \\
\hline & 竞 & $\begin{array}{c}\text { Type II Error } \\
5.59 \%\end{array}$ & Correct \\
\hline
\end{tabular}

Since this system did decrease overall errors drastically ${ }^{8}$, subsequent efforts focused on continuing to adjust the coefficients to reduce (or eliminate) the Type II error rate while still minimizing the Type I errors. Emphasis was placed on the Type II errors since they are more critical in terms of developing a system to be implemented at DWPF. The coefficients for each term of the revised index system (shown in Table 5-4) were adjusted in an attempt to meet the stated objectives. Additionally, a constant was added to the "Good" index to move the durability classification value to 0 from -0.24 . Thus, the revised index system (Revision 2) shown in Table 5-6 classifies glasses with positive scores as acceptable and negative or 0 scores as unacceptable - based on the $10 \mathrm{~g} / \mathrm{L}$ criterion.

\footnotetext{
${ }^{8}$ The overall errors (both Type I and Type II) decreased from 986 for the Brewer index system (see Table 5-2) to 342 for the Revision 1 index system (see Table 5-5). It should be noted that although the overall errors decreased, the Type II errors increased.
} 
WSRC-TR-2005-00239

Revision 0

Table 5-6. Revision 2 of the Index System.

\begin{tabular}{||c|c|c|c||}
\hline \hline \multicolumn{4}{|c||}{ Good Index } \\
\hline $\mathbf{A l}_{2} \mathbf{O}_{3}$ & $\mathbf{F e}_{2} \mathbf{O}_{3}$ & $\mathbf{Z r O}_{2}$ & Constant \\
\hline $\mathrm{Al}_{2} \mathrm{O}_{3} / 7$ & $\mathrm{Fe}_{2} \mathrm{O}_{3} / 20.5$ & $\mathrm{ZrO}_{2} / 10.5$ & 1.1 \\
\hline
\end{tabular}

\begin{tabular}{|c|c|c|c|}
\hline \multicolumn{4}{|c|}{ "Bad Index } \\
\hline $\mathrm{Na}_{2} \mathrm{O}$ & & & Alkali \\
\hline $\mathrm{Na}_{2} \mathrm{O} / 23$ & $\mathrm{Li}_{2} \mathrm{C}$ & Sum & lkali/21.5 \\
\hline & $\mathbf{B}_{2} \mathbf{O}_{3}$ & MgO & \\
\hline
\end{tabular}

Application of Revision 2 of the index system (as shown in Table 5-6) to the 2414 rows of data (Draft F) yielded 446 total errors (an increase from Revision 1 of 342 total errors). The Type I error percentage was $19.5 \%$ (as compared to $14.8 \%$ from Revision 1 ) and the Type II error rate was 3.1\%. The Type I error rate was viewed as being too conservative due to the potential for restricting access to composition regions of interest. In addition, Type II errors were committed indicated the lack of defining an AGCR.

In response to this observation, an additional term for the "Good" index was introduced. Based on a multivariate statistical regression of the components of glass to the $\mathrm{NL}$ [B] values, $\mathrm{U}_{3} \mathrm{O}_{8}$ and $\mathrm{CaO}$ were determined to be appropriate candidates as their correlations were the next largest after the other "Good" components. The addition of the $\mathrm{U}_{3} \mathrm{O}_{8}$ term did not enhance the index system's ability to partition the glasses. However, the addition and optimization of the $\mathrm{CaO}$ term did improve the index system's ability to partition the database. The resulting index system (referred to as the Taylor Index System) is shown in Table 5-7.

Table 5-7. The Taylor Index System.

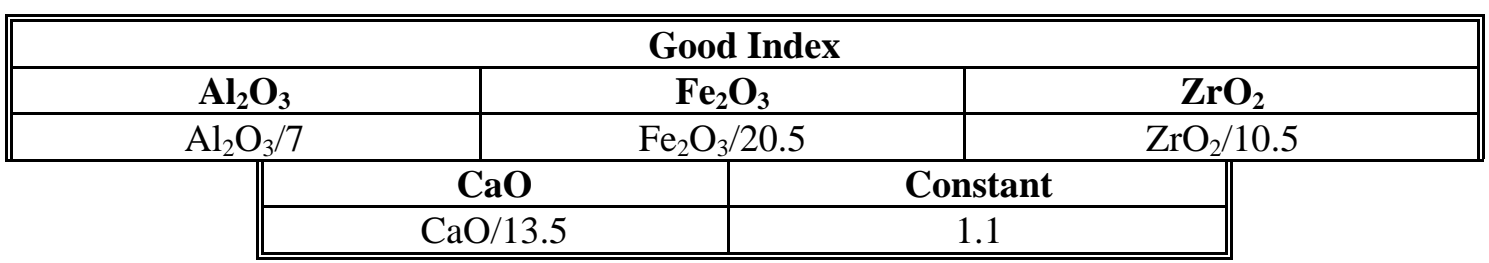

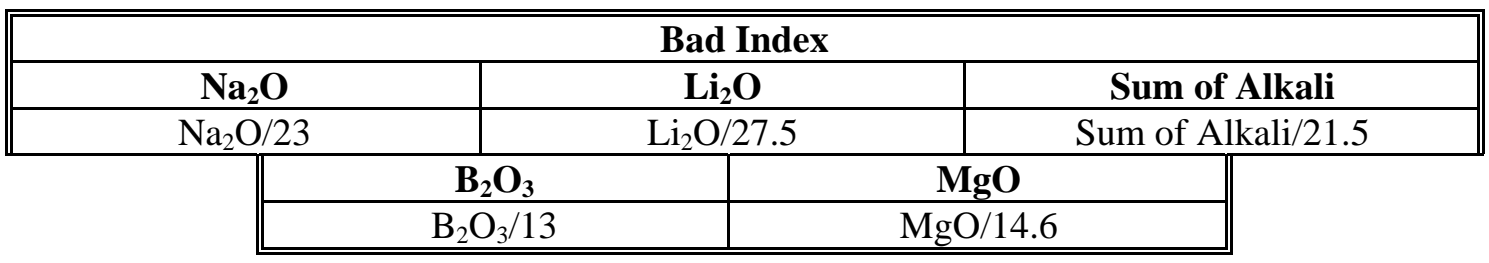

When the Taylor index system was applied to the 2414 rows of data (ComPro, Draft F), the results were encouraging (see Figure 5-1). The total number of errors produced was 269 which is lower than that observed with Revision 1 (342 total errors) and Revision 2 (446 total errors). In addition to decreasing the total errors, the partitioning of errors into Type I and Type II is 
favorable. Of the 269 total errors, 261 are Type I errors (a 11.6\% error rate), while only 8 are Type II errors (a 4.97\% error rate). Table 5-8 summarizes the application of the Taylor index system to the 2414 rows of glasses. Although a significant improvement in the Type I error rate, the Taylor Index System fails to define an AGCR.

The partitioning of the 2414 ComPro glasses in terms of the Taylor Index System versus NL [B] (measured) is shown in Figure 5-1. The 8 glasses resulting in Type II errors are shown in Figure 5-1 as "red circles or points" lying in the upper right hand quadrant. The 161 glasses defining the Type I errors are located in the bottom left hand quadrant of Figure 5-1. Those glasses lying in the lower right hand quadrant and upper left hand quadrant were correctly classified as acceptable and unacceptable, respectively.

In order to completely eliminate the Type II errors (i.e., correctly classify the eight "red" points) based on the Taylor Index system, one would have to shift the line of demarcation from 0.0 to 0.8. In doing so, one could define an AGCR but the shift would significantly increase the Type I error rate potentially making the Taylor Index system overly conservative (transitioning back toward the Brewer Index system results). Another option to eliminate the Type II errors could be to identify a common compositional thread among the eight glasses and implement either an additional terms in the index system or "prescreen" the database prior to applying the index system. The latter approach ("prescreening”) is discussed in Section 5.3.

Table 5-8. Classification Summary Using the Taylor Index System.

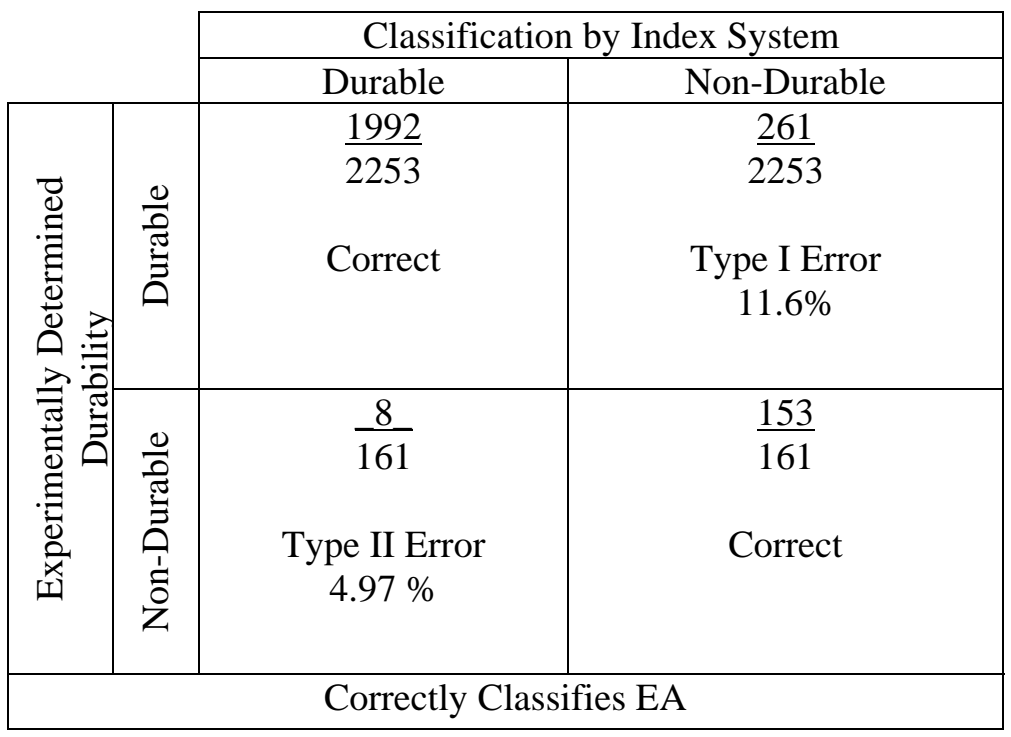




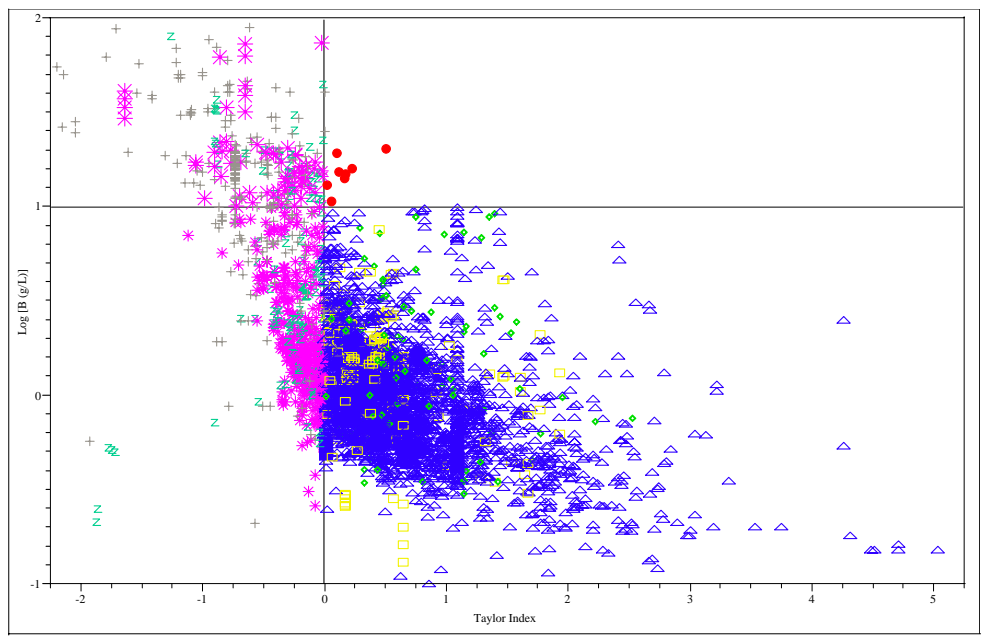

Figure 5-1. Taylor Index System Versus log NL [B] Release (g/L) for Model Data.

\subsection{Application of Taylor Index to Revision 0}

In this section, the Taylor Index system is applied to Revision 0 of the ComPro database. As previously noted, the primary difference between Draft F and Revision 0 was a slight reduction in the total number of glasses classified as quenched, "Model Data" (2214 glasses in Draft F versus 2406 glasses in Revision 0). Of these 2406 glasses, 161 have NL [B] $\geq 10 \mathrm{~g} / \mathrm{L}$, and 2245 glasses have NL [B] $<10 \mathrm{~g} / \mathrm{L} .{ }^{9}$ Table 5-9 summarizes the Type I and Type II errors rates once the Taylor Index system is applied to Revision 0. The total number of errors remained at $269-$ consistent with its application to Draft F. The \% Type I and \% Type II errors also remained constant at $11.6 \%$ and $4.97 \%$. Of particular interest are the 8 glasses that remained as Type II errors when the Taylor Index System was applied to both Draft F ("red" points in Figure 5-1) and Revision 0 of ComPro. The question at hand is: "Do these glasses have compositional similarities that may identify a component not currently captured in the Index System or that could provide a basis for 'prescreening' the database"? Table 5-10 summarizes the Glass IDs and compositional views (target, measured, or measured bias-corrected) of these eight glasses.

\footnotetext{
${ }^{9}$ The eight glasses which were not classified as quenched, "Model Data” in Revision 0 were all durable (NL [B] $<10$ $\mathrm{g} / \mathrm{L})$ glasses and correctly classified by the Taylor Index System.
} 
WSRC-TR-2005-00239

Revision 0

Table 5-9. Classification Summary Using the Taylor Index System to ComPro Revision 0.

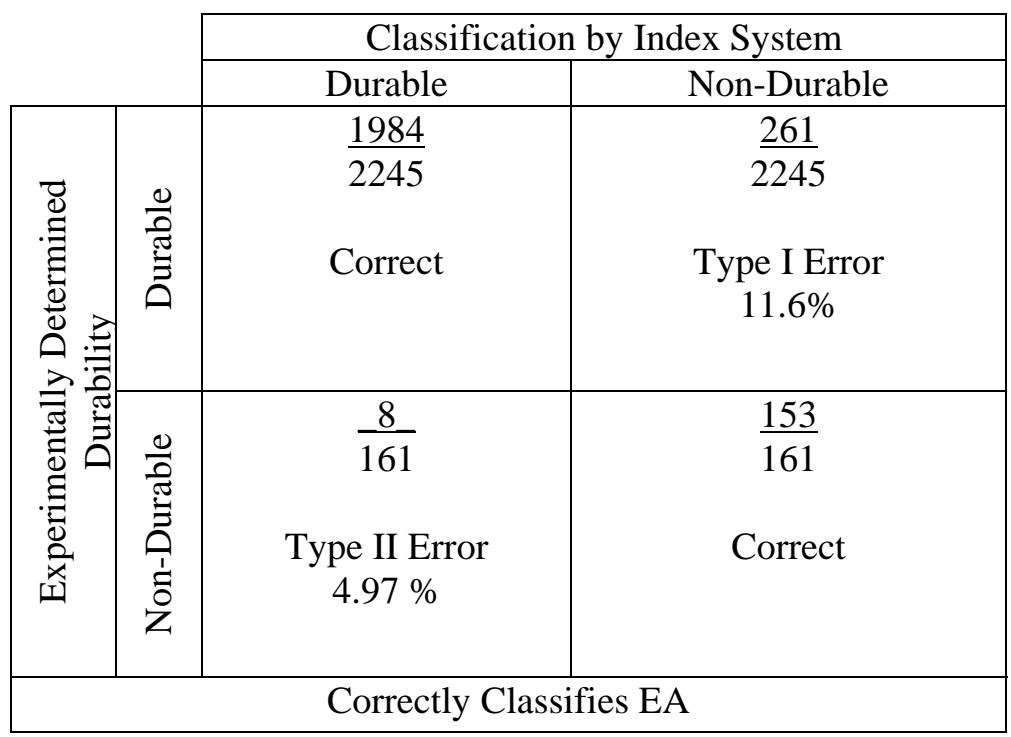

Table 5-10. Compositional Views (wt\%) of the Eight Type II Error Glasses.

\begin{tabular}{|c|c|c|c|c|c|c|c|c|}
\hline & $\begin{array}{c}\text { CVS2- } \\
30\end{array}$ & ND10 & ND10 & "ND19 & $\begin{array}{c}\text { IDMS } \\
\text { PX-5- } \\
6812\end{array}$ & R-4 & $\begin{array}{c}\text { PHA15 } \\
\text { FY99 }\end{array}$ & $\begin{array}{c}\text { PHA18 } \\
\text { FY99 }\end{array}$ \\
\hline & Target & Meas & Meas-bc & Target & Meas & Meas & Target & Target \\
\hline \multicolumn{9}{|l|}{ Oxide } \\
\hline $\mathrm{Al}_{2} \mathrm{O}_{3}$ & 4.58 & 5.0591 & 4.9528 & 3.0 & 3.26 & 2.711 & 3.227 & 3.22 \\
\hline $\mathrm{B}_{2} \mathrm{O}_{3}$ & 20.0 & 11.7687 & 11.3029 & 5.0 & 7.64 & 8.637 & 9.003 & 8.904 \\
\hline $\mathrm{BaO}$ & 0.179 & 0 & 0 & 0 & 0.09 & 0 & 0.114 & 0.114 \\
\hline $\mathrm{CaO}$ & 0 & 4.411 & 4.1605 & 0.5 & 0.92 & 1.02 & 1.23 & 1.228 \\
\hline $\mathrm{Cr}_{2} \mathrm{O}_{3}$ & 0.0224 & 0.0146 & 0.015 & 0 & 0.33 & 0.137 & 0.144 & 0.144 \\
\hline $\mathrm{CuO}$ & 0.0269 & 0 & 0 & 0 & 0.38 & 0.68 & 1.031 & 1.031 \\
\hline $\mathrm{Fe}_{2} \mathrm{O}_{3}$ & 13.2 & 14.9547 & 14.5211 & 18.0 & 12.63 & 12.7 & 13.467 & 13.466 \\
\hline $\mathrm{K}_{2} \mathrm{O}$ & 0 & 0 & 0 & 0 & 3.18 & 3.714 & 6.14 & 6.139 \\
\hline $\mathrm{Li}_{2} \mathrm{O}$ & 1.0 & 3.0087 & 2.9544 & 4.2 & 4.12 & 4.354 & 3.824 & 3.739 \\
\hline $\mathrm{MgO}$ & 0 & 3.7349 & 3.5208 & 0 & 1.43 & 1.2966 & 1.195 & 1.17 \\
\hline $\mathrm{MnO}_{2}$ & 0.0269 & 0.5581 & 0.5581 & 8.0 & 1.85 & 2.58 & 2.355 & 2.355 \\
\hline $\mathrm{Na}_{2} \mathrm{O}$ & 8.32 & 14.9625 & 13.743 & 13.44 & 11.43 & 10.497 & 8.659 & 8.734 \\
\hline $\mathrm{Nd}_{2} \mathrm{O}_{3}$ & 0.2209 & 0 & 0 & 0 & 0.1 & 0 & 0 & 0 \\
\hline $\mathrm{NiO}$ & 0.103 & 0.0636 & 0.0634 & 3.76 & 1.251 & 1.116 & 1.268 & 1.268 \\
\hline $\mathrm{P}_{2} \mathrm{O}_{5}$ & 0.0179 & 0.2291 & 0.2291 & 0 & 0 & 0 & 0.041 & 0.041 \\
\hline $\mathrm{PbO}$ & 0 & 0 & 0 & 0 & 0.14 & 0.125 & 0.132 & 0.132 \\
\hline $\mathrm{SiO}_{2}$ & 51.9 & 45.0323 & 44.3532 & 44.18 & 45.42 & 47.297 & 43.289 & 42.339 \\
\hline $\mathrm{SO}_{3}$ & 0.0493 & 0 & 0 & 0 & 0 & 0 & 0.197 & 0.197 \\
\hline $\mathrm{TiO}_{2}$ & 0 & 0.0584 & 0.0581 & 0 & 0.29 & 0.501 & 1.122 & 2.22 \\
\hline $\mathrm{U}_{3} \mathrm{O}_{8}$ & 0 & 0 & 0 & 0 & 0 & 0 & 2.731 & 2.731 \\
\hline $\mathrm{ZnO}$ & 0 & 0 & 0 & 0 & 0.11 & 0.119 & 0.117 & 0.118 \\
\hline $\mathrm{ZrO}_{2}$ & 0 & 0.0068 & 0.0068 & 0 & 0.71 & 1.206 & 0.149 & 0.149 \\
\hline
\end{tabular}


Based on a review of the various compositional views (see Table 5-10), there are concentrations of certain oxides that are potentially problematic (with respect to durability) from a glass formulation perspective (see "yellow" shaded cells). Initially, consider the $\mathrm{B}_{2} \mathrm{O}_{3}$ concentration of 20 wt\% in CVS2-30. High concentrations of $\mathrm{B}_{2} \mathrm{O}_{3}$ within silicate based systems can lead to amorphous phase separation which can have a negative impact on durability. Tovena et al. (1994) suggested that borosilicate glasses with $>14 \mathrm{wt} \% \mathrm{~B}_{2} \mathrm{O}_{3}$ can result in amorphous phase separation when the $\mathrm{Al}_{2} \mathrm{O}_{3}$ content is insufficient. Although the target $\mathrm{Al}_{2} \mathrm{O}_{3}$ concentration in CVS2-30 is $4.58 \mathrm{wt} \%$, the $\mathrm{B}_{2} \mathrm{O}_{3}$ concentration does exceed the $14 \mathrm{wt} \%$ mark. Thus the formation of amorphous phase separation is possible which could have a negative impact on the durability of the CVS2-30 glass. In addition, high concentrations of $\mathrm{CaO}$ and/or $\mathrm{MgO}$ could induce phase separation in borosilicate glasses as well - potentially bringing into question ND10's composition (both measured and measured bias corrected views).

Herman et al. (2002) provided compositional rules for DWPF with respect to $\mathrm{Al}_{2} \mathrm{O}_{3}$ content and/or sum of alkali. In fact, in terms of the SME acceptability process, DWPF imposes a lower $\mathrm{Al}_{2} \mathrm{O}_{3}$ limit of $3.0 \mathrm{wt} \%$ (without measurement uncertainties applied) coupled with an upper sum of alkali constraint of $19.3 \mathrm{wt} \%$. That is, glasses with at least $3 \mathrm{wt} \% \mathrm{Al}_{2} \mathrm{O}_{3}$ (but less than $4 \mathrm{wt} \%$ ) and less than $19.3 \mathrm{wt} \%$ sum of alkali are acceptable for processing. An alternative constraint for DWPF is to increase the lower $\mathrm{Al}_{2} \mathrm{O}_{3}$ limit from 3 to $4 \mathrm{wt} \%$ which, if compositionally satisfied, would not impose an upper alkali constraint over the experimental region that led to the constraint. When considering such constraints, ND-19 and R-4 (and perhaps IDMS-PX-5-6812, PHA15-FY99, and PHA18-FY99 all being $3.2 \mathrm{wt} \% \mathrm{Al}_{2} \mathrm{O}_{3}$ ) would fail to meet DWPF's $\mathrm{Al}_{2} \mathrm{O}_{3}$ acceptance criterion.

Given these observations and the potential impact on the durability response, a set of "prescreening” criteria were developed and used to screen ComPro (Revision 0) prior to the application of the Taylor Index System. This process could be viewed as an attempt to remove glass compositional regions potentially covered by ComPro which are suspected to lead to ambiguous PCT responses prior to application of the Index System. Table 5-11 summarizes the "pre-screening" criteria - glasses failing the criteria were removed from the ComPro database.

For example, glasses with $\mathrm{B}_{2} \mathrm{O}_{3}$ concentrations of $>14 \mathrm{wt} \%$ and $\mathrm{CaO}+\mathrm{MgO}$ concentrations $>6$ $\mathrm{wt} \%$ were removed due to possible influences of amorphous phase separation on durability. Glasses with $\mathrm{CuO}$ concentrations of $>0.63 \mathrm{wt} \%$ were screened from the database due to the imposed $\mathrm{CuO}$ solubility limit in PCCS. Finally, the $\mathrm{Al}_{2} \mathrm{O}_{3}$ and sum of alkali constraints were used to screen the database for glasses not considered processable in DWPF.

Table 5-11. "Pre-Screening” Criteria.

\begin{tabular}{|c|c|c|}
\hline Oxide & Constraint & Technical Basis \\
\hline $\mathrm{B}_{2} \mathrm{O}_{3}$ & $>14.0 \mathrm{wt} \%$ & Possible amorphous phase separation \\
\hline $\mathrm{Al}_{2} \mathrm{O}_{3}$ & $<3.0 \mathrm{wt} \%$ & Current PCCS SME acceptability limit \\
\hline $\mathrm{Al}_{2} \mathrm{O}_{3}+\sum$ alkali & $\begin{array}{c}\mathrm{Al}_{2} \mathrm{O}_{3}<4.0 \text { and } \\
\text { Ealkali }>19.3 \mathrm{wt} \%\end{array}$ & Current PCCS SME acceptability limit \\
\hline $\mathrm{CaO}+\mathrm{MgO}$ & $>6.0 \mathrm{wt} \%$ & Possible amorphous phase separation \\
\hline $\mathrm{CuO}$ & $>0.63 \mathrm{wt} \%$ & Current PCCS SME acceptability limit \\
\hline
\end{tabular}

Imposing these screening criteria on the 2406 ComPro glasses, 661 glasses were removed, leaving a total of 1745 glasses to which the Taylor Index System was applied. To provide a measure of how conservative these screening criteria were 524 of the 661 glasses had NL [B]'s 
less than $10 \mathrm{~g} / \mathrm{L}$ (experimentally determined acceptable glasses leading to the inability to access these compositional regions). Of the 1745 remaining glasses 1721 were experimentally determined to have NL [B]'s < $10 \mathrm{~g} / \mathrm{L}$ while 24 had NL [B]'s > $10 \mathrm{~g} / \mathrm{L}$.

Applying the Taylor Index system to the 1745 remaining glasses, 177 glasses were classified as "unacceptable" while 1568 glasses were classified as "acceptable”. Of the 177 glasses classified as "unacceptable" by the index system, 22 had measured boron releases $>10 \mathrm{~g} / \mathrm{L}$ (not durable), while 155 glasses has measured NL [B]'s < 10 g/L (a 9.0\% Type I error rate). Of the 1568 glasses classified as “acceptable” by the index system, 2 had measured NL [B]'s $>10 \mathrm{~g} / \mathrm{L}$ (a 8.3\% Type II error rate), while 1566 glasses had measured NL [B]'s < 10 g/L. Table 5-12 summarizes the Type I and Type II errors rates resulting upon applying the Taylor Index system to the "screened" ComPro database.

Based on these results, there does appear to be value in applying the "pre-screening" criteria to the ComPro database in terms of reducing the number of glasses whose experimentally determined PCT response exceeds the $10 \mathrm{~g} / \mathrm{L}$ mark (i.e., reduced from 161 to 24). However, in doing so, the compositional region defined by ComPro database was significantly altered as 661glasses (of which 524 were experimentally determined as durable) were eliminated. Thus use of the "pre-screening" criteria invokes a high degree of conservative to this approach. Even though the "pre-screening" criteria eliminated a significant fraction of the non-durable ComPro glasses (137 out of 161), imposing such constraints still did not result in an AGCR once the Taylor Index System was applied. Two glasses still remain within the compositional region defined by the Taylor Index System (after application of the "pre-screening" criteria). These two glasses are ND-19 (target) and IDMS-PX-5-6812 (measured) with NL [B]'s of $20.3 \mathrm{~g} / \mathrm{L}$ and 19.2 g/L respectively.

Table 5-12. Summary of Type I and Type II Errors After Applying the Taylor Index System to the "Screened" ComPro Database.

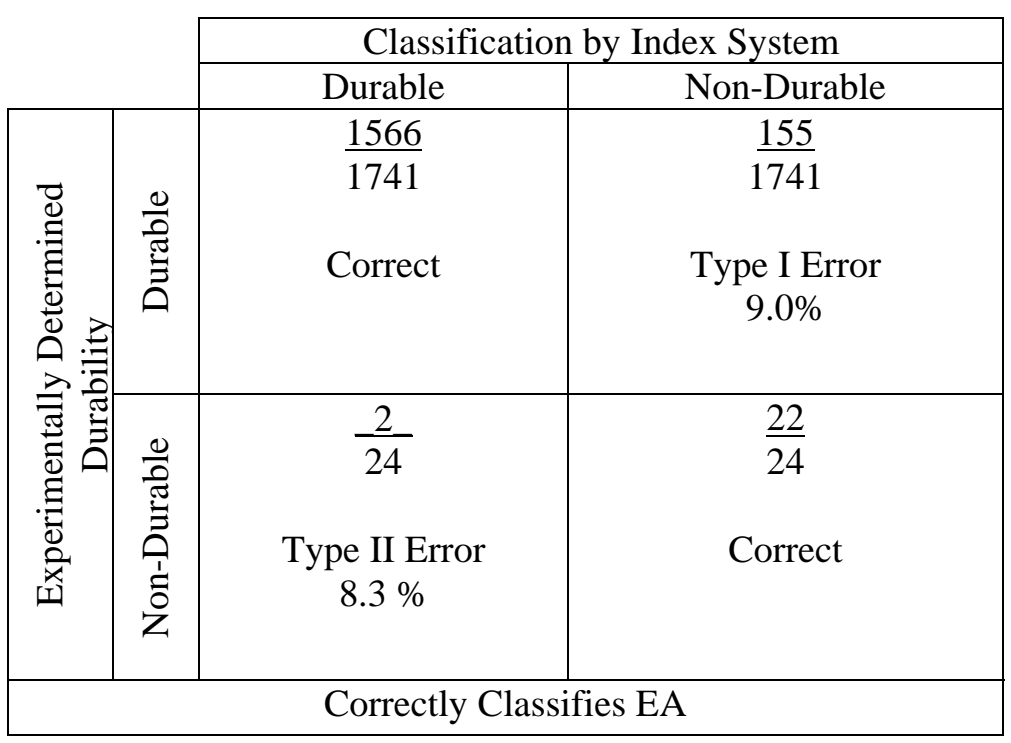


WSRC-TR-2005-00239

Revision 0

\subsection{PARTITIONING FUNCTION IN JMP}

A recently received version of the JMP software contains a feature referred to as an automated "partitioning" or "splitting" function. That is, a collection of data can be sequentially partitioned or split based on the best available specific criteria and variables. For example, consider the ComPro database as being a set of explanatory (independent) variables ("X"s, composition parameters) and response (dependent) variables ("or "Y"s; durability responses). The partitioning function in JMP allows for one to simply request the response variables ("Y"s or PCT responses) be split based on the most significant explanatory variable ("X" or composition factor). More specifically, the software will chose the oxide that most effectively partitions the PCT responses (NL [B]'s) - perhaps not 100\% effective based on a single oxide. Based on this initial split, a second request can be made to split a particular set of the "Y" values (good or bad PCTs) based on the next most critical " $X$ " variable. This process, which is purely data driven, can be repeated until the "best" partitioning is obtained.

Given the "Index System" is essentially a mechanism to "split" the ComPro database into two distinct groups (acceptable and unacceptable glasses based on the measured PCT response), the JMP function was used to ascertain if other compositional factors would more effectively partition the data than that observed with the previous index systems (thought to be based on glass science). Again, this approach is purely data driven with no fundamental or technical basis being applied (i.e., no specific glass science driving the selection of the oxides or the associated coefficients).

The initial request to partition the 2406 ComPro glasses resulted in the selection of $\mathrm{Al}_{2} \mathrm{O}_{3}$ and a value of $>3.75 \mathrm{wt} \%$ as the primary oxide and concentration, respectively, to most effectively partition the glasses based on the $10 \mathrm{~g} / \mathrm{L}$ criterion. In doing so, 1658 glasses were identified that satisfied the $\mathrm{Al}_{2} \mathrm{O}_{3}$ constraint. Of the 1658 glasses, 12 glasses (or $0.0072 \%$ ) had NL [B] greater than $10 \mathrm{~g} / \mathrm{L}$ (i.e., Type II errors - demonstrating that no single component can partition the database perfectly). When JMP was requested to select the next oxide to most effectively partition the 1658 glasses into "acceptable" and "unacceptable" glasses, $\mathrm{CaO}$ at a value of $\geq$ $0.616 \mathrm{wt} \%$ was identified. That is, 1447 glasses with $<3.75 \mathrm{wt} \% \mathrm{Al}_{2} \mathrm{O}_{3}$ and $\geq 0.616 \mathrm{wt} \% \mathrm{CaO}$ were identified of which only 2 glasses had "unacceptable” (measured) PCT responses. The third JMP request identified $\mathrm{MgO}$ with a critical value of $<3.521 \mathrm{wt} \%$ as a primary oxide. When applying the $\mathrm{Al}_{2} \mathrm{O}_{3}, \mathrm{CaO}$, and $\mathrm{MgO}$ criteria to the 2406 glasses, 1428 glasses are identified - all having acceptable PCT responses. With these three criteria, the JMP partitioning function did define or identify an AGCR - meeting programmatic objectives. The next obvious question is: "Does the compositional region defined by the AGCR allow access to higher alkali glasses to support the accelerated mission goals?"

The automated partitioning function screened or removed 978 of the 2406 ComPro glasses which did cause some initial concerns regarding excessive conservatism regardless of its ability to identify an AGCR within the entire Model, quenched ComPro data. However, a preliminary review of glasses within the 1428 "acceptable" glasses defining the ACGR includes glass systems of interest to support the accelerated mission. More specifically, the Frit 320 - SB3 glasses (ADT-5 and ADT-6) as well as the Frit 304 - SB2 glasses are included in the glasses meeting the $\mathrm{Al}_{2} \mathrm{O}_{3}, \mathrm{CaO}$, and $\mathrm{MgO}$ criteria identified by JMP. These glasses had previously been classified as "unacceptable" by the original durability limits although measured NL [B] were $<2 \mathrm{~g} / \mathrm{L}$. As a result, alternative frits, with lower measured melt rates, were recommended to DWPF. Therefore, in terms of conservatism, one cannot rule out the use of this simple set of criteria to not only 
establish an AGCR but an AGCR that appears to cover a compositional region including high alkali glasses which have been shown to improve melt rate and/or waste loading.

One of the most interesting features of the JMP outcome is the fact that, although glass science would have suggested an impact of $\mathrm{CaO}$ and $\mathrm{MgO}$ on durability, the magnitude of their impact is surprising. That is, glass science would not have isolated (or ranked as high) the significance of $\mathrm{CaO}$ and/or $\mathrm{MgO}$ as a complete compositional picture to map the durability response for multicomponent glass systems. Specifically, $\mathrm{SiO}_{2}$, one of the primary oxides (in terms of wt\%) of borosilicate glasses does not play a role in the JMP partitioning process - nor does $\mathrm{B}_{2} \mathrm{O}_{3}, \mathrm{Na}_{2} \mathrm{O}$, $\mathrm{Li}_{2} \mathrm{O}$, or a sum of alkali term. All of these oxides are known to play a significant role in defining the overall durability of a glass. For example, in the current durability model (Jantzen et al. 1995), the "coefficients" associated with $\mathrm{Li}_{2} \mathrm{O}$ and $\mathrm{Na}_{2} \mathrm{O}$ are the most negative (a detrimental impact on durability) of all the oxides tracked. $\mathrm{SiO}_{2}\left(\right.$ and $\left.\mathrm{Al}_{2} \mathrm{O}_{3}\right)$ are predicted to have two of the most positive coefficients. So from a glass science perspective, one has to ask the question: "Why are these oxides not associated with the JMP partitioning process?" That is, having a system to classify the durability response of borosilicate glasses based on three components is somewhat counter-intuitive (especially the three JMP identified) and a system that one would approach with some reluctance with respect to implementation (especially when the consequences are as high as those in the high level waste product performance arena).

The JMP process is purely data driven and empirically derived - glass science is not a factor and at best can be called upon to only help explain the outcome. However, the JMP process does result in the definition of a "true" AGCR - an accomplishment that was not met when "glass science" was introduced or used to guide the development and evolution of the index systems. In terms of accessing the compositional regions of interest, although the number of glasses the JMP system screens out is 978, the compositional region defining the AGCR appears not to limit specific systems of recent interest. In fact, Table 6-1 summarizes the minimum and maximum values for the acceptable glasses (1428 glasses) within the AGCR which all have acceptable (measured) PCT responses. ${ }^{10}$ The range of all the oxides of glasses with acceptable PCTs is extremely large. For example, consider some of the major oxides typically associated with DWPF glasses: $\mathrm{Al}_{2} \mathrm{O}_{3}, \mathrm{~B}_{2} \mathrm{O}_{3}, \mathrm{Fe}_{2} \mathrm{O}_{3}, \mathrm{Li}_{2} \mathrm{O}, \mathrm{Na}_{2} \mathrm{O}, \mathrm{SiO}_{2}$, and $\mathrm{U}_{3} \mathrm{O}_{8}$. The $\mathrm{Al}_{2} \mathrm{O}_{3}$ values range from 3.75 (min) to a maximum of $18 \mathrm{wt} \%$ for the durable glasses. Again, the minimum value (3.75 $\mathrm{wt} \%$ ) was selected by the JMP process to define the AGCR. The $\mathrm{B}_{2} \mathrm{O}_{3}$ values range from 1.37 to 18.43 wt\%. Currently DWPF would not process a "non-borosilicate” glass (i.e., less than approximately $5 \mathrm{wt} \% \mathrm{~B}_{2} \mathrm{O}_{3}$ ) and previous melt rate testing as well as potential phase separation issues would likely keep the $\mathrm{B}_{2} \mathrm{O}_{3}$ concentrations well below the $18 \%$ level. Minimum and maximum values for $\mathrm{Fe}_{2} \mathrm{O}_{3}$ are 0.0 to $\sim 21 \mathrm{wt} \%$ which is extremely large. With respect to DWPF and assuming $\mathrm{Fe}_{2} \mathrm{O}_{3}$ is not a frit component, this range would allow processing of sludges extremely high in $\mathrm{Fe}_{2} \mathrm{O}_{3}$ at relatively high WLs. It should also be noted that the AGCR glasses also cover a range of $\mathrm{FeO}$ values indicating that glasses with induced REDOX states (i.e., not fully oxidized) are also contained within the AGCR defined by the JMP system. The ranges for both $\mathrm{Na}_{2} \mathrm{O}$ and $\mathrm{Li}_{2} \mathrm{O}$ are also extremely robust. $\mathrm{Na}_{2} \mathrm{O}$ values for the 1428 durable glasses range from 4.773 to $24 \mathrm{wt} \%$ while $\mathrm{Li}_{2} \mathrm{O}$ values range from 0.0 to $8.177 \mathrm{wt} \%$. Based on current glass formulation strategies, these ranges would appear to bound desired alkali contents to improve melt rate and/or waste loadings - while maintaining product performance issues as demonstrated by the JMP partitioning process based on historical measured data. The $\mathrm{SiO}_{2}$ concentrations of the AGCR glasses range from 30 to $73 \%$ - again an extremely broad concentration range. The

\footnotetext{
${ }^{10}$ Table 6-1 summarizes only the ranges of the "major" oxides which are defined as the maximum limit being $\geq 0.5 \mathrm{wt} \%$ in glass. For a complete listing of all the oxides that define AGCR, refer to Appendix A.
} 
minimum and maximum $\mathrm{U}_{3} \mathrm{O}_{8}$ values are 0.00 and $8.258 \mathrm{wt} \%$, respectively - which should encompass most projected DWPF sludges at reasonable WLs.

Based on a review of the minimum and maximum ranges for the durable glasses defining the AGCR, the compositional region over which they reside appears to be extremely large with the high probability of supporting the accelerated mission goals at DWPF. In addition, one of the most critical concepts to any potentially implementable, alternative durability constraint or system is the ability to "successfully" classify the EA glass as non-durable. Given a "true" AGCR has been defined by the JMP partitioning function, correct classification of the EA glass has been met by default.

It is recognized that the effectiveness of the three-component system to define the AGCR was based solely on the use of a $10 \mathrm{~g} / \mathrm{L}$ NL [B] limit to define an "acceptable” PCT response. Although this definition is consistent with the limit used by Edwards and Brown (1998) to set the Salkali and $\mathrm{Al}_{2} \mathrm{O}_{3}$ criteria for relaxing the homogeneity constraint from the MAR to the PAR and is also considered to be conservative relative to the EA glass as reported by Jantzen et al. (1993) with uncertainties considered, the WAPS also addressed the normalized releases of Li and $\mathrm{Na}$ relatively to the EA glass. An obvious question to address is: "Do all the glasses within the AGCR defined based on a NL [B] also met the requirements for Li and Na releases?” Jantzen et al. (1993) report the normalized Li and Na releases for EA (without uncertainties) to be 9.565 and 13,346 g/L, respectively. Applying a 2 sigma uncertainty to these values results in lower acceptance values of 8.095 and $11.542 \mathrm{~g} / \mathrm{L}$ for $\mathrm{Li}$ and $\mathrm{Na}$, respectively. ${ }^{11}$ A review of the 1428 glasses that define the AGCR indicates that the maximum Li and Na releases are 6.132 and 7.22 $\mathrm{g} / \mathrm{L}$ - all well below the EA acceptance values including uncertainties.

In addition to effectiveness and potential advantages of such a simple system to assess durability, one additional assessment should be made to determine if there is any incentive to further pursue the three-component system with respect to access to compositional regions of interest as compared to the current durability model using the "proposed" limits as defined by Edwards et al. (2003). The assumption is made that access to higher alkali regions is desired as historical experimental data indicate that improvements to melt rate and/or waste loading can be achieved as glass systems extend into higher alkali regions. The higher alkali regions have also been the regions which challenge durability predictions. To make an assessment of "incentive" one only has look to a study that was initially designed to assess the impact of lower $\mathrm{Li}_{2} \mathrm{O}$ concentrations on melt rate. In addition to assessments of melt rate, a series of glasses were developed to challenge the "proposed" durability limits. More specifically, glasses were designed to be both "acceptable" and "unacceptable" based on model predictions. The transition from "acceptable" to "unacceptable" was primarily based on an increase in total alkali content which ranged from $20 \%$ to $24 \%$. The durability of these glasses were evaluated via the PCT and the normalized releases ranged between $0.7645 \mathrm{~g} / \mathrm{L}$ (Low-Li-4 ccc) and $1.1079 \mathrm{~g} / \mathrm{L}$ (Low-Li-1 quenched) (Peeler and Edwards 2005). The results indicated that all the glasses were very acceptable as compared to the $16.695 \mathrm{~g} / \mathrm{L}$ for EA even though most of the glasses were predicted to be non-durable ("unacceptable”) based on the current durability model even with the "proposed" limits. This suggests that there is additional "conservatism" in the current durability model and associated limits which may restrict access to higher alkali regions. An assessment of the glasses via the JMP partitioning function would suggest the glasses are acceptable - agreeing with experimental results.

\footnotetext{
${ }^{11}$ Jantzen et al. (1993) report the standard deviations for $\mathrm{Li}$ and $\mathrm{Na}$ to be 0.735 and 0.902 , respectively for
} the EA glass. 
Table 6-1. Minimum and Maximum Oxide Values (Major Oxides Only) of the AGCR.

\begin{tabular}{||c|c|c||}
\hline \hline Oxide & Min & Max \\
\hline $\mathrm{Al}_{2} \mathrm{O}_{3}$ & 3.750 & 18.000 \\
\hline $\mathrm{B}_{2} \mathrm{O}_{3}$ & 1.370 & 18.430 \\
\hline $\mathrm{BaO}$ & 0.000 & 3.870 \\
\hline $\mathrm{CaO}$ & 0.616 & 15.000 \\
\hline $\mathrm{CdO}$ & 0.000 & 1.230 \\
\hline $\mathrm{Ce}_{2} \mathrm{O}_{3}$ & 0.000 & 1.440 \\
\hline $\mathrm{CeO}_{2}$ & 0.000 & 2.050 \\
\hline $\mathrm{Cr}_{2} \mathrm{O}_{3}$ & 0.000 & 2.375 \\
\hline $\mathrm{Cs}_{2} \mathrm{O}$ & 0.000 & 1.160 \\
\hline $\mathrm{CuO}$ & 0.000 & 1.398 \\
\hline $\mathrm{Fe}_{2} \mathrm{O}_{3}$ & 0.000 & 21.007 \\
\hline $\mathrm{FeO}$ & 0.000 & 3.994 \\
\hline $\mathrm{K}_{2} \mathrm{O}$ & 0.000 & 8.089 \\
\hline $\mathrm{La}_{2} \mathrm{O}_{3}$ & 0.000 & 5.000 \\
\hline $\mathrm{Li}_{2} \mathrm{O}$ & 0.000 & 8.177 \\
\hline $\mathrm{MgO}_{3} \mathrm{O}$ & 0.000 & 3.240 \\
\hline $\mathrm{MnO}_{2}$ & 0.000 & 2.510 \\
\hline $\mathrm{MnO}_{\mathrm{MoO}}$ & 0.000 & 20.600 \\
\hline $\mathrm{MoO}_{3}$ & 0.000 & 1.670 \\
\hline $\mathrm{Na}_{2} \mathrm{O}$ & 4.773 & 24.000 \\
\hline $\mathrm{Nb}_{2} \mathrm{O}_{5}$ & 0.000 & 2.239 \\
\hline $\mathrm{Nd}_{2} \mathrm{O}_{3}$ & 0.000 & 5.960 \\
\hline $\mathrm{NiO}_{2}$ & 0.000 & 4.870 \\
\hline $\mathrm{P}_{2} \mathrm{O}_{5}$ & 0.000 & 4.739 \\
\hline $\mathrm{RuO}_{2}$ & 0.000 & 0.625 \\
\hline $\mathrm{SiO}_{2}$ & 30.000 & 73.000 \\
\hline $\mathrm{SO}_{3}$ & 0.000 & 1.607 \\
\hline $\mathrm{SrO}_{2}$ & 0.000 & 10.130 \\
\hline $\mathrm{ThO}_{2}$ & 0.000 & 5.240 \\
\hline $\mathrm{TiO}_{2}$ & 0.000 & 5.380 \\
\hline $\mathrm{U}_{3} \mathrm{O}_{8}$ & 0.000 & 8.258 \\
\hline $\mathrm{UO}_{2}$ & 0.000 & 2.870 \\
\hline $\mathrm{V}_{2} \mathrm{O}_{5}$ & 0.000 & 5.696 \\
\hline $\mathrm{ZnO}_{\mathrm{ZnO}}$ & 0.000 & 4.269 \\
\hline $\mathrm{Cl}_{2}$ & 0.000 & 14.000 \\
\hline & 0.000 & 0.782 \\
\hline & 0.000 & 7.330 \\
\hline & \\
\hline & & \\
\hline
\end{tabular}




\subsection{IMPLEMENTATION ISSUES}

In this section, implementation issues (real or potential) are discussed in reference to both the Index System and the JMP partitioning function. Separate discussions are warranted given the differences in approaches (i.e., glass science versus data driven) as well as the differences in results (in terms of defining an AGCR).

\subsection{Index System Approach}

The expectation for the index system was to develop a simple, compositional-dependent set of constraints that could effectively partition existing PCT data into acceptable and unacceptable categories based on a pre-defined, durability acceptance level. To aid in the development of the constraints, two criteria or metrics were used to easily assess the partitioning effectiveness and to provide a basis from which changes could be made. These metrics were the Type I and Type II error rates as defined in Section 3.0. Minimizing the Type I errors would eliminate potential conservatism in the approach and potentially increase access to composition regions that improve melt rate or increase waste loading for DWPF. With respect to the Type II errors, one would not only like to minimize but to eliminate this type of error given it is the more critical error (classifying a glass as acceptable when the measured NL [B] response is greater than $10 \mathrm{~g} / \mathrm{L}$ ). In fact, a true AGCR requires that this type of error be eliminated with high confidence.

Direct application of Brewer's index system and even the application of its modified form, the Taylor system, did not lead to the definition of an AGCR. Figure 7-1 shows three graphics: the far left graphic representing the historical composition and durability data, the middle graphic representing the goal of this task (an index system that yields an ideal AGCR), and the far right graphic reflecting the current status of the index system. The current status graphic depicts that errors are still generated when the index system is applied to the historical glass composition and durability data. More specifically, application of the Taylor index system to the compiled database resulted in 8 of the 2414 glasses being classified as "acceptable" whose measured durability response was "unacceptable” (> $10 \mathrm{~g} / \mathrm{L}$ ) - a 5\% Type II error rate.

\section{Historical Database of Glass Compositions and PCTs \\ (O unacceptable PCT)}

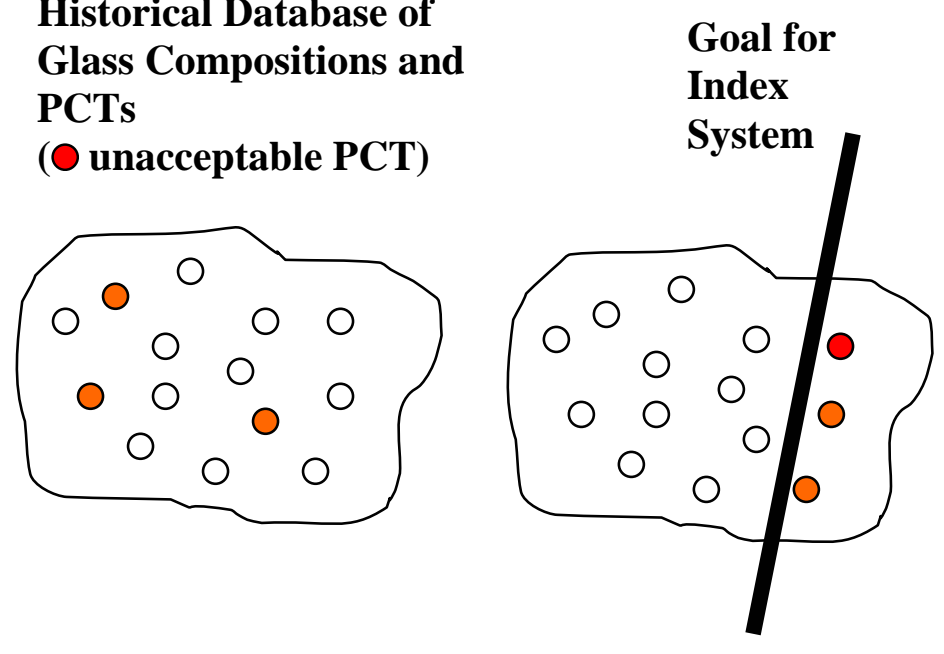

Figure 7-1. Historical Data, the Goal for the Index System, and the Current Status 
Since development of the index system resulted in a less than ideal AGCR, this leads to an inability to define or apply uncertainties to the partitioning function; that is, it results in an illdefined confidence statement regarding the system's ability to predict durability of the next glass. It has been demonstrated that the index system can partition the existing data effectively but the fact there is a $5 \%$ probability of a Type II error, lowers the confidence of using this system to predict with confidence the durability response for the next "unknown" (with respect to its actual PCT response) glass based solely on the composition of that glass. If an index system could be developed which partitioned the glasses perfectly (i.e., a 0\% Type II error rate) one would then have a system that could potentially be implemented. However, based on the current status of the Taylor Index System, this may result in an extremely high Type I error rate which would overly restrict the composition regions of interest (a condition to be avoided with respect to accelerated mission goals). Otherwise, from a conceptual viewpoint and assuming Type II errors do exist, there may be an island (or islands) of unacceptable glasses within a much broader composition region defined by acceptable glasses. The inability of the index system to discern these durability response regions may be a reflection of the complex relationship or interaction between the individual components. Although the selection of the components that define the "good" and "bad" indices generally agrees with glass science theory on their effects on durability, there are interactive effects that are not captured in the index system. Given the index system was empirically derived, there is no fundamental model basis (either theoretical or statistical) from which uncertainties could be developed in an attempt to provide a confidence statement with respect to acceptability. Therefore, the use of the Index System without eliminating all Type II errors is deemed inadequate for implementation at DWPF.

\subsection{JMP Partitioning Function Approach}

As discussed in Section 5.4, the JMP partitioning process is purely data driven and empirically derived. However, the JMP process does result in the definition of a "true" AGCR based on the use of compositional limits or criteria associated with $\mathrm{Al}_{2} \mathrm{O}_{3}, \mathrm{CaO}$, and MgO. The definition of an AGCR is an accomplishment that was not met when "glass science" was used to guide the development of the Brewer Index system and evolution of the Taylor Index system. With respect to implementation, having a 3-component system to classify the durability response of multicomponent borosilicate glasses is conceptually "troubling” at this stage of development maturity. However, one has to acknowledge its effectiveness (100\% accurate in eliminating Type II errors while not overly conservative in terms of committing Type I errors based on the historical data evaluated). In addition, a three component system to assess durability may be advantageous with respect to minimizing the number of components required for measurement to support process control. Although there are potential advantages to this approach, one also has to acknowledge the presence of potential limitations and/or implementation issues which primarily revolve around the lack of technical maturity. Implementation issues or questions increasing the uncertainty of this system include (1) the need for and/or the definition of uncertainties (i.e., measurement, prediction, etc) in the process control strategy and (2) uncertainty (technical or political) in using a "bounding" PCT response ( $10 \mathrm{~g} / \mathrm{L})$ to establish acceptability relative to the use of a modelbased prediction. At this stage of the development process, one would have to consider the 3component system as a meaningful tool for process control as "premature" until further work can be performed to identify and address all of the implementation issues. Although preliminary success was achieved, conceptually this process is pushing process control strategies into "uncharted" territory which must be further developed prior to implementation. 
WSRC-TR-2005-00239

Revision 0

\subsection{SUMMARY}

The term AGCR refers to a glass composition region in which the durability response (as defined by the PCT) is less than some pre-defined, acceptable value that satisfies the WAPS. More specifically, the intent of the AGCR is to define a multi-dimensional composition region, through the use of single- or multi-component constraints imposed on the composition of HLW glasses, whose PCT responses are deemed acceptable. As previously discussed, the question of interest for this task was whether or not a set of rules and constraints could be established that uses the chemical compositions of the glasses to effectively generate an equivalent partitioning of the PCTs. Over the course of the efforts to meet this objective, two approaches were assessed. The first (referred to as the "Index System") was based on the use of an evolving system of compositional constraints which were used to explore the possibility of defining an AGCR. This approach was primarily based on "glass science" insight to establish the compositional constraints. The second approach (referred to as the "JMP partitioning process") was strictly a data driven, empirical method used to partition or split the historical composition - durability information based on the "best" available oxides. The basis for comparing the effectiveness of both approaches to partition the ComPro database revolved around tracking the two types of classification errors that could be generated by this system: Type I errors (classifying an acceptable PCT as unacceptable) and Type II errors (classifying an unacceptable PCT as acceptable). Of these two types of errors, Type II is the more serious.

Initially, the Brewer index system was applied to a preliminary version (Draft F) of the ComPro database. Revisions to the Brewer index system were found to be necessary, and this report detailed the changes made and the efficiency of the revised system (the Taylor Index System) to partition the ComPro PCT data. When the Taylor index system was applied to the 2406 rows of quenched, "Model Data" within ComPro (Revision 0), the results were encouraging but did not meet programmatic objectives. On a positive note, the Taylor Index System correctly classified the EA composition as non-durable. For an index system to meet the intent of the WAPS, it must classify the EA glass as "unacceptable" based on its reference composition since it is the "benchmark" in terms of durability acceptance. In addition, the Type I errors were minimized to an error rate of $11.6 \%$ which allowed access to composition regions of interest to improve melt rate or increase waste loadings for DWPF as compared to the current durability model (i.e., Frit 320 - SB3 glasses). However, the Taylor Index System had a Type II error rate (the more critical error) of 4.97\%. Therefore, a "true" AGCR was not defined and without eliminating all Type II errors this approach was deemed inadequate for further implementation consideration at the DWPF.

The second approach (the JMP partitioning process) was purely data driven and empirically derived - glass science was not a factor. In this approach, the collection of composition durability data in ComPro was sequentially partitioned or split based on the best available specific criteria and variables. More specifically, the JMP software chose the oxide $\left(\mathrm{Al}_{2} \mathrm{O}_{3}\right.$ for this dataset) that most effectively partitions the PCT responses (NL [B]'s) - perhaps not $100 \%$ effective based on a single oxide. Based on this initial split, a second request was made to split a particular set of the "Y" values (good or bad PCTs based on the $10 \mathrm{~g} / \mathrm{L}$ limit) based on the next most critical " $X$ " variable. This "splitting" or "partitioning" process was repeated until an AGCR was defined based on the use of only 3 oxides $\left(\mathrm{Al}_{2} \mathrm{O}_{3}, \mathrm{CaO}\right.$, and $\left.\mathrm{MgO}\right)$ and critical values of $>$ $3.75 \mathrm{wt} \% \mathrm{Al}_{2} \mathrm{O}_{3}, \geq 0.616 \mathrm{wt} \% \mathrm{CaO}$, and $<3.521 \mathrm{wt} \% \mathrm{MgO}$. Using this set of criteria, the ComPro database was partitioned in which no Type II errors were committed. The automated partitioning function screened or removed 978 of the 2406 ComPro glasses which did cause some 
WSRC-TR-2005-00239

Revision 0

initial concerns regarding excessive conservatism regardless of its ability to identify an AGCR. However, a preliminary review of glasses within the 1428 "acceptable" glasses defining the ACGR includes glass systems of interest to support the accelerated mission.

With respect to implementation, having a 3-component system to classify the durability response of multi-component borosilicate glasses is conceptually "troubling" at this stage of development maturity. However, one has to acknowledge its effectiveness (100\% accurate in eliminating Type II errors while not overly conservative in terms of committing Type I errors based on the historical data evaluated). In addition, a three component system to assess durability may be advantageous with respect to minimizing the number of components required for measurement to support process control. Although there are potential advantages to this approach, one also has to acknowledge the presence of potential limitations and/or implementation issues which primarily revolve around the lack of technical maturity. 
WSRC-TR-2005-00239

Revision 0

\subsection{RECOMMENDATIONS}

The following recommendations are made based on the status of the current work scope.

(1) Further development of (or adjustments to) the Taylor Index System to define an AGCR should not be considered.

(2) Perform additional experimental work to challenge the 3-component system in terms of durability response. In the development of the test matrix glasses, not only should glasses be identified that challenge the JMP 3-component system and/or current durability approach, but they should also reside in a compositional region in which process properties ( $T_{L}$ and viscosity) are satisfied.

a. If successful, identification of an implementation strategy should be highly considered.

b. If unsuccessful, consider the development of "new" criteria via the JMP partitioning process to handle "outliers".

(3) Assess the use of the minimum and maximum values defining the AGCR to support variability study assessments or decisions regarding the need to perform additional experimental work. 
WSRC-TR-2005-00239

Revision 0

\subsection{REFERENCES}

ASTM 2002. Standard Test Methods for Determining Chemical Durability of Nuclear Waste Glasses: The Product Consistency Test (PCT), ASTM C-1285-2002.

Brewer, TK, TB Edwards, and DK Peeler. 2003. Defining an Acceptable Glass Composition Region (AGCR) Through the Use of Compositional-Based Constraints: A Preliminary Assessment of Durability, WSRC-TR-2003-00385, Revision 0, Westinghouse Savannah River Company, Aiken, South Carolina.

Brown, KG, RL Postles, and TB Edwards. 2002. SME Acceptability Determination for DWPF Process Control, WSRC-TR-95-0364, Revision 4, Westinghouse Savannah River Company, Aiken, South Carolina.

Cozzi, AD, TB Edwards, and DK Peeler. 2003. Durability Assessments of High Alkali Glasses in Support of the Accelerated Clean-Up Mission: Experimental Results of the "ND" Glasses, WSRC-TR-2003-00287, Revision 0, Westinghouse Savannah River Company, Aiken, South Carolina.

Edwards, TB, and KG Brown. 1998. Evaluating the Glasses Batched for the Tank 42 Variability Study, SRT-SCS-98-017, Revision 0, Westinghouse Savannah River Company, Aiken, South Carolina.

Edwards, TB, DK Peeler, and SL Marra. 2004. Revisiting the Prediction Limits for Acceptable Durability, WSRC-TR-2003-00510, Revision 0, Westinghouse Savannah River Company, Aiken, South Carolina.

Feng, X, MJ Schweiger, PR Hrma, DK Peeler, H Li, SE Palmer, DE Smith, YB Peng, JH Westsik, and CN Wilson. 1995. Vendor Glass Durability Study During Evaluation of Melter System Technologies for Vitrification of Hanford Low-Level Wastes, Emerging Technologies in Hazardous Waste Management VII, American Chemical Society, Washington, DC, p. 2.

Herman, CC, TB Edwards, DR Best, DM Marsh, and RJ Workman. 2002. Reduction of Constraints: Phase 2 Experimental Assessment for Sludge-Only Processing, WSRC-TR-200200482, Revision 0, Westinghouse Savannah River Company, Aiken, South Carolina.

Jantzen CM, NE Bibler, DC Beam, CL Crawford, and MA Pickett. 1993. Characterization of the DWPF Environmental Assessment (EA) Glass Standard Reference Material (U), WSRC-TR92-346, Revision 1, Westinghouse Savannah River Company, Aiken, South Carolina.

Jantzen, CM, JB Pickett, KG Brown, TB Edwards, and DC Beam. 1995. Process/Product Models for the Defense Waste Processing Facility (DWPF): Part I. Predicting Glass Durability from Composition Using a Thermodynamic Hydration Energy Reaction Model (THERMO), WSRC-TR-93-672, Revision 1, Volume 1, Westinghouse Savannah River Company, Aiken, South Carolina. 
Lambert, DP, TH Lorier, DK Peeler, and ME Stone. 2001. Melt Rate Improvement for DWPF MB3: Summary and Recommendations, WSRC-TR-2001-00148, Westinghouse Savannah River Company, Aiken, South Carolina.

Li, H, JG Darab, PA Smith, X Feng, and DK Peeler. 1995. Chemical Durability of Low-Level Simulated Nuclear Waste Glasses with High Concentrations of Minor Components (Cl, F, P, S, and $\mathrm{Cr}$ ), Proceedings of the INMM $36^{\text {th }}$ Annual Meeting, Volume XXIV, pp. $460-465$.

Occhipinti, JE. 2003. Technical Task Request, Durability Model/Waste Loading Studies for DWPF, TTR-HLW/DWPF/TTR-03-0012, Westinghouse Savannah River Company, Aiken, South Carolina.

Peeler, DK, TH Lorier, DF Bickford, DC Witt, TB Edwards, KG Brown, IA Reamer, RJ Workman, and JD Vienna. 2001. Melt Rate Improvement for DWPF MB3: Frit Development and Model Assessment, WSRC-TR-2001-00131, Revision 0, Westinghouse Savannah River Company, Aiken, South Carolina.

Peeler, DK and TB Edwards. 2002. Frit Development for Sludge Batch 3, WSRC-TR-200200491, Revision 0, Westinghouse Savannah River Company, Aiken, South Carolina.

Peeler DK, TB Edwards, and CC Herman. 2003. Task Technical and QA Plan: Durability Model/Waste Loading Studies for DWPF, WSRC-RP-2003-00495, Revision 0, Westinghouse Savannah River Company, Aiken, South Carolina.

Peeler, DK, TB Edwards, and AS Taylor. 2004a. The Impact of the Proposed $\Delta G_{P}$ Limits on Glass Formulation Efforts: Part I. Model-Based Assessments, WSRC-TR-2004-00203, Revision 0, Westinghouse Savannah River Company, Aiken, South Carolina.

Peeler, DK, TB Edwards, and AS Taylor. 2004b. The Impact of the Proposed $\Delta G_{P}$ Limits on Glass Formulation Efforts: Part II. Experimental Results, WSRC-TR-2004-00348, Revision 0, Westinghouse Savannah River Company, Aiken, South Carolina.

Peeler, DK and TB Edwards. 2005. Low Li $i_{2} \mathrm{O}$ Frits: Selecting Glasses to Support Melt Rate Studies and Challenge Current Durability Models, WSRC-TR-2005-00306, Revision 0, Westinghouse Savannah River Company, Aiken, South Carolina

Smith, ME, DH Miller, and TM Jones. 2004. Slurry-Fed Melt Rate Furnace Test for the SB3/Frit 320 Feed System, WSRC-TR-2004-00459, Revision 0, Westinghouse Savannah River Company, Aiken, South Carolina.

Snyder, TK, TB Edwards, JC George, AS Taylor, and DK Peeler. 2004. Data Qualification Report: SRNL Glass Composition - Properties (ComPro ${ }^{T M}$ ) Database, WSRC-RP-2004-00705, Revision 0, Westinghouse Savannah River Company, Aiken, South Carolina.

Taylor, AS, TB Edwards, JC George, TK Snyder, and DK Peeler. 2004. The SRNL Composition - Properties (ComPro) Database, WSRC-RP-2004-00704 Revision 0, Westinghouse Savannah River Company, Aiken, South Carolina.

Tovena I, T Advocat, D Ghaleb, E Vernaz and F Larche. 1994. “Thermodynamic and Structural Models Compared with the Initial Dissolution Rates of SON Glass Samples,” Sci. Basis for Nucl. 
Waste Mgt., XVII, A. Barkatt and R.A. Van Konynenburg (Eds.), Mat. Res. Soc., Pittsburgh, PA, 595-602 (1994).

Vienna, JD, P Hrma, A Jiricka, DE Smith, TH Lorier, IA Reamer, and RL Schulz. 2001. Hanford Immobilized LAW Product Acceptance Testing: Tanks Focus Area Results, PNNL13744, Pacific Northwest National Laboratory, Richland, Washington.

Vienna, JD, D.S. Kim, and P. Hrma. 2002. Database and Interim Glass Property Models for Hanford HLW and LAW Glasses, PNNL-14060, Pacific Northwest National Laboratory, Richland, Washington.

Waste Acceptance Product Specifications (WAPS). 1996. Office of Environmental Management, Waste Acceptance Product Specifications for Vitrified High-Level Waste Forms, Revision 2, USDOE Document EM-WAPS, U.S. Department of Energy, Germantown, Maryland. 
WSRC-TR-2005-00239

Revision 0

\section{Appendix A}

Minimum and Maximum Values Defining the Durable AGCR Glasses 
Table A.1. Minimum and Maximum Oxide Ranges Defining the AGCR.

\begin{tabular}{|c|c|c|}
\hline Oxide & Min & Max \\
\hline $\mathrm{Ag}_{2} \mathrm{O}$ & 0.000 & 0.240 \\
\hline $\mathrm{Al}_{2} \mathrm{O}_{3}$ & 3.750 & 18.000 \\
\hline $\mathrm{As}_{2} \mathrm{O}_{3}$ & 0.000 & 0.050 \\
\hline $\mathrm{B}_{2} \mathrm{O}_{3}$ & 1.370 & 18.430 \\
\hline $\mathrm{BaO}$ & 0.000 & 3.870 \\
\hline $\mathrm{Bi}_{2} \mathrm{O}_{3}$ & 0.000 & 0.060 \\
\hline $\mathrm{CaO}$ & 0.616 & 15.000 \\
\hline $\mathrm{CdO}$ & 0.000 & 1.230 \\
\hline $\mathrm{Ce}_{2} \mathrm{O}_{3}$ & 0.000 & 1.440 \\
\hline $\mathrm{CeO}_{2}$ & 0.000 & 2.050 \\
\hline $\mathrm{CoO}$ & 0.000 & 0.130 \\
\hline $\mathrm{Co}_{2} \mathrm{O}_{3}$ & 0.000 & 0.100 \\
\hline $\mathrm{Cr}_{2} \mathrm{O}_{3}$ & 0.000 & 2.375 \\
\hline $\mathrm{Cs}_{2} \mathrm{O}$ & 0.000 & 1.160 \\
\hline $\mathrm{Cu}_{2} \mathrm{O}$ & 0.000 & 0.297 \\
\hline $\mathrm{CuO}$ & 0.000 & 1.398 \\
\hline $\mathrm{Fe}_{2} \mathrm{O}_{3}$ & 0.000 & 21.007 \\
\hline $\mathrm{FeO}$ & 0.000 & 3.994 \\
\hline $\mathrm{Gd}_{2} \mathrm{O}_{3}$ & 0.000 & 0.014 \\
\hline $\mathrm{HgO}$ & 0.000 & 0.010 \\
\hline $\mathrm{K}_{2} \mathrm{O}$ & 0.000 & 8.089 \\
\hline $\mathrm{La}_{2} \mathrm{O}_{3}$ & 0.000 & 5.000 \\
\hline $\mathrm{Li}_{2} \mathrm{O}$ & 0.000 & 8.177 \\
\hline $\mathrm{MgO}$ & 0.000 & 3.240 \\
\hline $\mathrm{MnO}_{2}$ & 0.000 & 2.510 \\
\hline $\mathrm{MnO}$ & 0.000 & 20.600 \\
\hline $\mathrm{MoO}_{3}$ & 0.000 & 1.670 \\
\hline $\mathrm{Na}_{2} \mathrm{O}$ & 4.773 & 24.000 \\
\hline $\mathrm{Nb}_{2} \mathrm{O}_{5}$ & 0.000 & 2.239 \\
\hline $\mathrm{Nd}_{2} \mathrm{O}_{3}$ & 0.000 & 5.960 \\
\hline $\mathrm{NiO}$ & 0.000 & 4.870 \\
\hline $\mathrm{P}_{2} \mathrm{O}_{5}$ & 0.000 & 4.739 \\
\hline $\mathrm{PbO}$ & 0.000 & 0.326 \\
\hline $\mathrm{PdO}_{2}$ & 0.000 & 0.010 \\
\hline $\mathrm{PdO}$ & 0.000 & 0.137 \\
\hline $\mathrm{Pr}_{2} \mathrm{O}_{3}$ & 0.000 & 0.003 \\
\hline $\mathrm{Pr}_{6} \mathrm{O}_{11}$ & 0.000 & 0.164 \\
\hline $\mathrm{Rb}_{2} \mathrm{O}$ & 0.000 & 0.082 \\
\hline $\mathrm{ReO}_{2}$ & 0.000 & 0.005 \\
\hline $\mathrm{Re}_{2} \mathrm{O}_{7}$ & 0.000 & 0.100 \\
\hline $\mathrm{Rh}_{2} \mathrm{O}_{3}$ & 0.000 & 0.082 \\
\hline $\mathrm{RhO}_{2}$ & 0.000 & 0.010 \\
\hline
\end{tabular}


WSRC-TR-2005-00239

Revision 0

\begin{tabular}{||c|c|c||}
\hline Oxide & Min & Max \\
\hline $\mathrm{RuO}_{2}$ & 0.000 & 0.625 \\
\hline $\mathrm{Sb}_{2} \mathrm{O}_{3}$ & 0.000 & 0.000 \\
\hline $\mathrm{Sb}_{2} \mathrm{O}_{5}$ & 0.000 & 0.200 \\
\hline $\mathrm{SeO}_{2}$ & 0.000 & 0.357 \\
\hline $\mathrm{SiO}_{2}$ & 30.000 & 73.000 \\
\hline $\mathrm{Sm}_{2} \mathrm{O}_{3}$ & 0.000 & 0.082 \\
\hline $\mathrm{SnO}$ & 0.000 & 0.060 \\
\hline $\mathrm{SnO}_{2}$ & 0.000 & 0.066 \\
\hline $\mathrm{SO}_{3}$ & 0.000 & 1.607 \\
\hline $\mathrm{SrO}$ & 0.000 & 10.130 \\
\hline $\mathrm{TeO}_{2}$ & 0.000 & 0.130 \\
\hline $\mathrm{ThO}_{2}$ & 0.000 & 5.240 \\
\hline $\mathrm{TiO}_{2}$ & 0.000 & 5.380 \\
\hline $\mathrm{Tl}_{2} \mathrm{O}_{3}$ & 0.000 & 0.451 \\
\hline $\mathrm{U}_{3} \mathrm{O}_{8}$ & 0.000 & 8.258 \\
\hline $\mathrm{UO}_{2}$ & 0.000 & 2.870 \\
\hline $\mathrm{V}_{2} \mathrm{O}_{5}$ & 0.000 & 5.696 \\
\hline $\mathrm{WO}_{3}$ & 0.000 & 0.009 \\
\hline $\mathrm{Y}_{2} \mathrm{O}_{3}$ & 0.000 & 0.082 \\
\hline $\mathrm{ZnO}$ & 0.000 & 4.269 \\
\hline $\mathrm{ZrO}_{2}$ & 0.000 & 14.000 \\
\hline $\mathrm{Br}_{-}$ & 0.000 & 0.078 \\
\hline $\mathrm{Cl}_{-}$ & 0.000 & 0.782 \\
\hline $\mathrm{F}-$ & 0.000 & 7.330 \\
\hline $\mathrm{I}-$ & 0.000 & 0.013 \\
\hline \hline
\end{tabular}




\section{Distribution}

E. W. Holtzscheiter, SRNL

D. A. Crowley, 999-W

S. L. Marra, 999-W

T. B. Calloway, 999-W

N. E. Bibler, SRNL

C.M. Jantzen, SRNL

J. R. Harbour, SRNL

G. C. Wicks, SRNL

D. K. Peeler, 999-W

T. K. Snyder, 999-W

T. B. Edwards, SRNL
C. C. Herman, SRNL

A. D. Cozzi, 999-W

M. E. Smith, 999-W

J. M. Pareizs, SRNL

C. L. Crawford, SRNL

M.S. Miller, 704-S

J.E. Occhipinti, 704-S

R.M. Hoeppel, 704-27S

J.F. Iaukea, 704-30S

J.W. Ray, 704-S 